\title{
(I)Migrantes, diversidades e desigualdades no sistema educativo português: balanço e perspectivas.
}

\author{
Maria José Casa-Nova
}

\section{RESUMO}

O objectivo do presente artigo consiste em procurar transmitir um olhar sociologicamente informado no que concerne à situação portuguesa no domínio das políticas educativas públicas e investigações produzidas relacionadas com o sistema educativo e a (i)migração, ou seja, com a tentativa de construção de uma educação intercultural.

Neste sentido, será realizada uma análise descritiva e compreensivo-interpretativa da evolução desta problemática em Portugal desde que a mesma se tornou objecto de reflexão por parte de investigadores/ as e políticos nos finais da década de oitenta, início da década de noventa do século XX.

Nesta análise, será

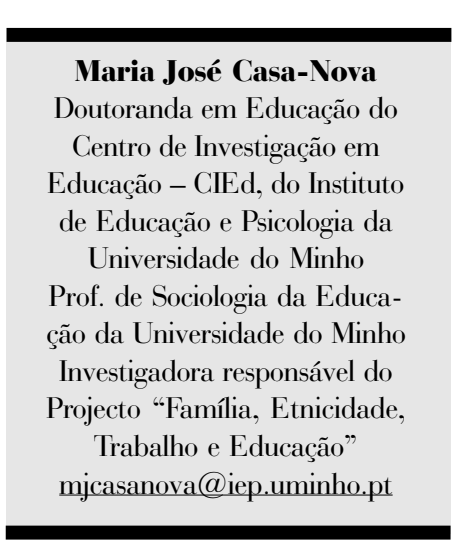
ABSTRACT
(Im)migrants, diversities and inequalities in the Portuguese educational system: an accounting and perspectives

The aim of this article consists in attempting to transmit a sociologically informed view in what the Portuguese situation in the field of public policies and research related to the educational system and (im)migration are concerned, that is, in attempting to construct an intercultural education. In this way, a descriptive and comprehensivedada ênfase às investigações e quadros teóricos produzidos e às medidas legislativas e políticas educativas no domínio do tratamento da diferença cultural dentro do sistema educativo português.

Palavras-chave: (I)Migração. Diferença. Educação intercultural. interpretative analysis of the evolution of this problem in Portugal will be realized, since the latter became an object of reflection on the part of researchers and politicians towards the end of the 80s, the beginning of the 90s of the XXth century. In this analysis, emphasis will be given on 
the research and theoretical frameworks produced and on the legislative measures and educational policies in the field of treating cultural difference in the Portuguese educational system.

Keywords: (Im)Migration. Difference. Intercultural education.

\section{RESUMEN}

\section{(I)Migración, diversidades $y$ desigualdades en el sistema educativo portugués: balance $y$ perspectivas}

El objectivo de esto artículo tiene a ver con procurar transmitir una perspectiva sociologicamente informada en lo que concierne à situación portuguesa en el âmbito de las políticas educativas públicas y investigaciones producidas relacionadas con el sistema educativo y la (in)migración, esto és, con la tentativa de construción de una educación intercultural

En éste sentido, intentaremos hacer una análisis descriptiva y comprensivo-

interpretativa de la evolución de ésta problemática en Portugal desde que la misma se ha volvido objecto de reflexión de los/as investigadores/as y políticos en el final de la década de ochenta, início de noventa del siglo XX.

En ésta análisis será dada ênfasis a las investigaciones y cuadros teóricos producidos y a las medidas legislativas y políticas educativas en el domínio de la diferencia cultural dentro del sistema educativo português.

Palabras clave: (In)Migración.

Diferencia. Educación Intercultural.

\section{Introdução}

Durante vários séculos, com especial incidência no século XIX e primeira metade do século XX, Portugal foi basicamente um país exportador de mão-de-obra não qualificada para diversos países do mundo. Até sensivelmente 1960 assistiu-se a uma emigração fundamentalmente para o Continente Americano (Brasil, E.U.A. e Argentina), tendo emigrado para este Continente, entre 1900 e 1960, cerca de 1,5 milhões de portugueses, dos quais $70 \%$ para o Brasil. A partir daquela data, a emigração passou a dirigir-se fundamentalmente para a Europa, com os portugueses a emigrarem sobretudo para França e República Federal Alemã. Entre 1960 e 1974 emigraram para França mais de $1 \mathrm{mi}$ Ihão de portugueses, sendo este actualmente o país com a maior comunidade portuguesa emigrada, seguido do Brasil' . A partir de 1973 assiste-se a uma diminuição da emigração devido à crise económica mundial derivada do choque petrolífero motivado pela guerra Israelo-Árabe, nunca mais voltando a atingir os valores anteriores à crise. Gradualmente assistiu-se a uma diminuição da emigração de carácter permanente (superior a um ano) e a um aumento da emigração de carácter temporário (igual ou inferior a um ano) sendo esta de $8 \%$ em 1977, de 53,1\% em 1993, e, em 2003, de 75,2\%, processando-se principalmente para a França e para a Suíça e, em menor número, para o Reino Unido?.

\footnotetext{
1 Para um aprofundamento da problemática da emigração portuguesa ver, entre outros, Maria Beatriz Nizza da Silva e outros (1993), Maria loannis Baganha, João Ferrão e Jorge Malheiros (1998) e José Luís Garcia (2000). Para um balanço do fenómeno e/imigratório português em termos de números e investigações produzidas, ver Maria loannis Baganha e Pedro Góis (1998/99). Para uma análise dos fenómenos migratórios tendo em atenção os processos de globalização, ver Maria loannis Baganha (2001).

${ }^{2}$ Ver Instituto Nacional de Estatística - INE - , disponível em: http:// www.ine.pt
} 
Até 1992 os números da emigração são ainda superiores aos números da imigração, assistindo-se a uma inversão gradual desta tendência a partir de 1993, ano a partir do qual o número de entradas ultrapassou o número de saídas, mantendo-se esta tendência até ao presente.

De acordo com o Instituto Nacional de Estatística - INE -, no ano de 2003 emigraram 27.008 indivíduos, 93,5\% dos quais para a Europa, valor aproximado ao verificado no ano 2002 (27.358 indivíduos, 81,3\% dos quais emigraram também para a Europa). Apesar do abrandamento significativo da emigração, actualmente estima-se em 5 milhões o número de portugueses e seus descendentes a viver em diversos países do mundo, ou seja, cerca de $50 \%$ da população residente em Portugal.

\section{Evolução da imigração}

Apesar da imigração em Portugal ser um fenómeno com várias décadas de existência, no decurso dos últimos seis anos, com particular incidência nos anos de 2000 a 2002, assistiu-se a um aumento extraordinário da imigração, fundamentalmente com origem nos $\mathrm{Pa}$ íses do Leste Europeu (principalmente da Ucrânia, mas também da Moldávia, da Roménia e da Rússia) e da América do Sul (principalmente do Brasil), transformando Portugal, país tradicionalmente de emigração, num país simultaneamente "exportador" e "importador" de mão-de-obra, na sua grande maioria para o exercício de funções não qualificadas, no domínio da agricultura e da construção civil. ${ }^{3}$

Se de 1975 a 1999 se assistiu a um aumento gradual dos contingentes de imigrantes, passando de $30 \mathrm{mil}$ para $191 \mathrm{mil}$, sem grandes saltos migratórios (ver quadro 1 em anexo), entre 2000 e 2002 esse número duplicou, constituindo actualmente cerca de 4,5\% da população portuguesa (cerca de 450 mil indivíduos legalizados em $10 \mathrm{mi}$ lhões e 500 mil habitantes), não se incluindo naquele número os imigrantes em processo de legalização (53 mil inscritos) ${ }^{4}$, os imigrantes em situação ilegal (que se estimam em mais de 50 mil) ${ }^{5}$, e a minoria étnica cigana (totalizando entre 40 a 50 mil elementos) dado esta não ser considerada imigrante, mas uma "minoria endógena" 6 uma vez que faz parte da sociedade portuguesa há mais de cinco séculos. ${ }^{7}$ Estes números significam a presença em

\footnotetext{
${ }^{3}$ Saliente-se que os cidadãos portugueses que emigram vão ocupar, nos países ditos de "acolhimento", o mesmo tipo de postos de trabalho que os imigrantes ocupam em Portugal.

${ }^{4}$ Este processo de legalização, permitido pela Lei da Imigração (D.L. n 34/2003, de 12 de Março), teve início a 3 de Maio de 2004 e termo a 14 de Junho do mesmo ano, prevendo que todos os imigrantes com entrada legal no país até ao dia 12 de Março de 2003, que tivessem efectuado descontos para o fisco e para a Segurança Social nos três últimos meses anteriores àquela data, pudessem legalizar a sua situação. Todos os imigrantes que não reuniam aquelas condições foram excluídos deste processo.

${ }^{5} \mathrm{~A}$ título de exemplo referimos o facto de, num processo de legalização para imigrantes brasileiros realizado em 2003 ao abrigo do chamado "acordo Lula" (realizado quando da visita do presidente brasileiro a Portugal), de 31 mil inscritos apenas 10 mil conseguiram terminar esse processo. Chamamos também a atenção para o facto de, apesar dos números oficiais relativos à presença de imigrantes de origem chinesa em Portugal apontarem para cerca de 5 mil, a Associação de imigrantes chineses referir que aquele número é superior a 15 mil.

${ }^{6}$ Expressão de Habermas (1994 apud TAYLOR, 1998).

${ }^{7}$ Embora se tenha também assistido a fenómenos imigratórios de cidadãos ciganos provenientes da Roménia, mas com uma, até ao presente, relativamente reduzida expressão numérica.
} 
Portugal de cerca de $6 \%$ de população culturalmente diferenciada da população portuguesa. ${ }^{8}$

As primeiras imigrações numericamente significativas registradas entre 1975 e 1999, realizaram-se a partir dos Países Africanos de Língua Oficial Portuguesa (os chamados PALOP - CaboVerde, Angola, S. Tomé e Príncipe, Guiné-Bissau e Moçambique) ${ }^{9}$, com particular incidência em Cabo-Verde que, até ao final do ano de 2000, se constituiu no país exportador do maior número de imigrantes, saldando-se, naquela data, em cerca de 50 mil os cidadãos caboverdianos a residir em Portugal, sendo posteriormente ultrapassado pela Ucrânia e actualmente pelo Brasil.

Presentemente fazem parte da sociedade portuguesa cidadãos oriundos de quase todos os países do mundo, com particular relevância numérica para os cidadãos provenientes (e por ordem decrescente) do Brasil, Ucrânia, Cabo-Verde, Angola, Guiné-Bissau, Reino Unido, Espanha, Alemanha, Moldávia, Roménia, França, Estados Unidos, S. Tomé e Príncipe, Rússia e Países Baixos, fazendo de
Portugal um país crescentemente étnico e culturalmente heterogéneo. ${ }^{10}$

Do ponto de vista da sua distribuição geográfica, e de acordo com o SEF (Serviço de Estrangeiros e Fronteiras), o Distrito de Lisboa concentra mais de $50 \%$ da população imigrante (predominando aqui os imigrantes dos PALOP - mais de 80.000 -, da União Europeia e do Brasil), seguindose os distritos de Faro (com predominância dos imigrantes oriundos da União Europeia), Setúbal (com predominância de imigrantes dos PALOP e União Europeia) e Porto (com predominância de imigrantes da União Europeia, Brasil e, em menor número, dos PALOP), situando-se todos estes distritos no litoral do país. Com um número de imigrantes significativamente inferior seguem-se, por ordem decrescente, os distritos de Aveiro, Coimbra, Braga e Leiria (entre 11 e 5 mil imigrantes) ${ }^{11}$. Os imigrantes de Leste (Ucrânia, Moldávia, Roménia e Rússia), dado ser uma imigração relativamente recente, não existem ainda dados relativos à sua distribuição geográfica, embora se considere que uma parte significativa dos mesmos se concentre onde as grandes obras de construção civil se realizam, nomeadamente em Lisboa.

\footnotetext{
${ }^{8}$ Ver quadro 1 em anexo. De salientar que o aumento extraordinário verificado entre 2000 e 2001 não significa uma entrada de quase 150 mil imigrantes naquele período de tempo, resultando também da introdução de uma nova figura jurídica: as Autorizações de Permanência (D.L. 4/2001), concedidas pelo período de um ano (renovável) a imigrantes com proposta de contrato de trabalho. $O$ asterisco $\left(^{*}\right)$ nos anos de 2001 a 2003 significa que aqueles números incluem, não só os imigrantes com Autorização de Residência (Permanente e Temporária - Lei de 20/98 de 12 de Maio), mas também os imigrantes com Autorização de Permanência. Os detentores de título de residência temporário podem permanecer em território português por um período de 2 anos renováveis; os detentores de título de residência permanente, como o próprio nome indica, não têm limitações de ordem temporal.

${ }^{9}$ Países Africanos de colonização portuguesa.

${ }^{10}$ Ver Quadro 2 em anexo, onde se dá conta das dezoito nacionalidades mais representadas em Portugal, embora em território português se encontrem cidadãos "provenientes de 170 países que falam 230 línguas diferentes" (MATOS, 2003).

Refira-se que, em termos profissionais, uma parte significativa dos cidadãos oriundos dos países da União Europeia e dos Estados Unidos são trabalhadores qualificados, quadros superiores de empresas, intelectuais e cientistas. Os imigrantes dos PALOP empregam-se, na sua grande parte, os homens na construção civil e as mulheres no trabalho doméstico; os imigrantes dos países de Leste, apesar de parcialmente apresentarem qualificações académicas de nível superior, empregam-se onde a mão-de-obra é mais necessária, ou seja, os homens na agricultura e na construção civil, as mulheres no trabalho doméstico e na restauração. 11 SEF - Dados provisórios de 2003.
} 


\section{Imigração, minorias étnicas e escolaridade}

\author{
A emergência da \\ problemática em Portugal
}

Apesar de a imigração em Portugal ser um fenómeno com várias décadas de existência (embora inicialmente com menor representatividade), o facto de os primeiros contingentes de imigrantes serem oriundos dos PALOP, países de colonização portuguesa cujos cidadãos, por essa razão, possuíam maioritariamente nacionalidade portuguesa, teve como consequência um não atender à diferença, dado considerar-se que aqueles imigrantes eram conhecedores da cultura e língua portuguesas uma vez que tinham sido socializados na escola nessa mesma língua e cultura. Quando os filhos desses imigrantes chegaram à escola e começaram a apresentar insucessos repetidos, Portugal começou gradualmente a "acordar" para a realidade multicultural da sua sociedade e da instituição educativa, desfazendo-se assim, a partir do "problema" do insucesso escolar de minorias, "o mito da homogeneidade cultural" (CORTESÃO; PACHECO, 1991) 12.

De facto, e como refere Dietz (2003, p. 59), "a porta de entrada do multiculturalismo no sistema educativo foi a discussão acerca do rendimento escolar das crianças provenientes de minorias (étnicas, culturais, religiosas, etc.)", não se pensando o multiculturalismo na escola a partir de referenciais positivos de troca de saberes e experiências entre grupos socioculturais diferenciados. Ou seja, a discussão em torno da problemática do multiculturalismo nas escolas (e nas sociedades no seu todo), resultou de se perspectivar o multiculturalismo como um "problema" a resolver ("problema" também este perspectivado a partir da sociedade maioritária) tendo apenas como foco de análise os imigrantes e descendentes de imigrantes de classes sociais e minorias étnicas desfavorecidas, oriundos de países desfavorecidos. Isso significa que, por exemplo, imigrantes provenientes da União Europeia, como Ingleses, Franceses, Alemães, etc., não são normalmente perspectivados como "imigrantes" mas como "estrangeiros", cujo processo de integração não se coloca, mesmo que possuam redes de sociabilidade próprias e os seus descendentes frequentem escolas próprias, vivendo à margem da sociedade de "acolhimento"13.

Do ponto de vista político, assistiu-se à tomada de algumas medidas de política social e educativa e à criação de alguns organismos com vista à tentativa de resolução do "problema", assistindo-se a uma procura de soluções que frequentemente resultam da percepção do "outro" como o problema, negligenciando-se o facto de, para o "outro" o problema sermos

\footnotetext{
${ }^{12} \mathrm{No}$ entanto, enquanto em países como os Estados Unidos ou a Inglaterra, este movimento teve a sua origem "de baixo para cima", resultando de reivindicações com origem nos grupos migrantes, em Portugal, este movimento teve origem "de cima para baixo", iniciando-se nas Universidades e no Governo nos finais dos anos 80, início dos anos 90 do século XX, quer no que diz respeito a investigações relativas à integração sociocultural e escolar dos migrantes, quer no que diz respeito a medidas de política social e educativa públicas. Apesar de não ser aqui objecto de análise, não podemos também de deixar de considerar neste processo a importância da adesão de Portugal à União Européia em 1986 e as políticas preconizadas pela EU neste domínio. Pela maior permanência temporal em Portugal e pelas maiores dificuldades de integração sociocultural e escolar que a sociedade maioritária considera que apresentam, quer do ponto de vista das investigações produzidas sobre a construção multicultural da sociedade portuguesa, quer do ponto de vista das medidas de política educativa, o ponto de partida foram os imigrantes oriundos dos PALOP (com uma incidência maior nos cabo-verdianos) e a minoria étnica cigana.

${ }^{13}$ Quando falamos em integração entendemos pelo conceito "um processo horizontal, não subordinado, de influências recíprocas entre todos os grupos socioculturais" (CASA-NOVA, 2002), que inclua "as visões e posições dos interessados, através de uma análise profunda das suas estratégias, relações e projectos [...]" (CARRASCO et al., 2001).
} 
"nós". Procura-se resolver os problemas através da tomada de medidas de carácter paliativo e não da tentativa de compreensão e resolução das causas subjacentes às situações percepcionadas pela maioria como problema.

Do ponto de vista da escola não se tem desenvolvido uma preocupação com a justiça, negligenciando a complexidade que the é inerente, sendo frequente a existência de uma "justiça escolar oficial" (ESTÊVÃO, 2002), evidenciada numa igualitarização de tratamento que se traduz, no plano procedimental e das interacções entre sujeitos-actores educativos, em injustiças de vária ordem, sendo necessário, na perspectiva de Estêvão (2001), questionar em que medida as organizações educativas desenvolvem no seu interior práticas promotoras de "justiça organizacional" ${ }^{14}$

Do ponto de vista curricular, pode-se considerar que após a Revolução de 25 de Abril de 1974, "o debate sobre a democratização da escola centrou-se nas questões da igualdade de oportunidades e nos processos pedagógicos que favorecessem a aprendizagem escolar, não fazendo, ainda, parte da agenda desse debate a situação de grupos culturais minoritários e com características afastadas das normas valorizadas pela cultura-padrão" (LEITE, 2002b, p. 71). Por razões relativas à concepção homogénea da formação sociocultural portuguesa, no início dos anos 80 a multiculturalidade continuava ausente dos currículos escolares, pensando-se a resolução do in- sucesso escolar a partir da concepção das crianças e jovens como "sistemas deficitários" a quem era preciso "compensar", fazendo "tábua rasa" dos conhecimentos apreendidos nos processos de socialização e educação familiares. A partir do início dos anos 90, "a presença nas escolas de alunos filhos de imigrantes africanos ou de populações regressadas das ex-colónias portuguesas pressionou os professores e a própria administração a agirem face a situações de exclusão a que esses alunos eram votados. As referências às relações entre o sucesso educativo e a atenção às especificidades dos alunos foi ganhando novos sentidos e foram incluindo aspectos de ordem cultural" (LEITE, 2002b, p. 80-81), procedendo-se, do ponto de vista do poder central, à implementação de projectos que tinham por objectivo diminuir o insucesso escolar partindo do reconhecimento da diversidade cultural.

\section{Uma caracterização da população escolar migrante}

Os números fornecidos pelo Secretariado Entreculturas para o ano lectivo de 1999/ 2000 (último ano para o qual existem números conhecidos) $)^{15}$ indicam, num universo de 1.247.183 alunos a frequentar o ensino obrigatório (do $1^{\circ}$ ao $9^{\circ}$ ano) e o ensino secundário (do $10^{\circ}$ ao $12^{\circ}$ ano), a presença de 86.333 alunos imigrantes e descendentes de imigrantes, ciganos e ex-emigrantes, representando $6,9 \%$ do total de alunos ${ }^{16}$. $\mathrm{Se}$ considerarmos os alunos imigrantes e

\footnotetext{
${ }^{14}$ Para uma análise da escola enquanto organização e da realização da escola democrática a seguir ao 25 de Abril, analisando os níveis de participação dos diferentes actores sociais, ver Licínio Lima (1992).

15 Os dados sobre a escolarização de crianças e jovens imigrantes ou descendentes de imigrantes e de minorias étnicas relativos ao Ensino Obrigatório (6 aos 15 anos) e ao Ensino Secundário (de três anos) foram fornecidos pelo Secretariado Coordenador dos Programas de Educação Multicultural (SCOPREM) criado em 1991 e actualmente denominado de Secretariado Entreculturas. Os dados relativos aos anos escolares posteriores a 1999/2000 não estão ainda disponíveis por aquele Secretariado, razão pela qual não são aqui objecto de análise.

${ }^{16} \mathrm{~A}$ inclusão de alunos descendentes de ex-emigrantes deve-se ao facto de, para muitos daqueles, nascidos em solo não português e frequentemente tendo iniciado o seu percurso escolar no país de imigração dos progenitores, o retorno destes a Portugal significar para os seus descendentes a "imersão" num país relativamente "estrangeiro", demonstrando dificuldades de integração escolar e de domínio da Língua Portuguesa.
} 
descendentes de imigrantes e os alunos ciganos, o seu número é de 67.401, totalizando $5,4 \%$ da população escolar. Se consideramos apenas os alunos imigrantes e descendentes de imigrantes, o seu número é de 59.371 , representando $4,8 \%$ da totalidade dos alunos para aquele ano lectivo.

Relativamente à sua distribuição geográfica, e considerando os alunos imigrantes e descendentes de imigrantes e os alunos de cultura cigana, o distrito com maior concentração é o distrito de Lisboa (44\%), seguido dos distritos de Setúbal (16\%), Faro (7\%), Porto $(6,2 \%)$ e Aveiro (6\%). Se considerarmos também os alunos descendentes de ex-emigrantes, a hierarquia da distribuição geográfica por distrito é relativamente alterada: Lisboa e Setúbal mantêm os primeiros lugares, seguindo-se os distritos de Aveiro, Porto e Faro.

Segundo Seabra e Mateus (2003), existe uma clara predominância de alunos originários de Cabo-Verde e Angola (representando mais de $40 \%$ do total de alunos), sendo que $60 \%$ dos alunos imigrantes e descendentes de imigrantes se concentram na Área Metropolitana de Lisboa (AML - que integra vários conselhos dos distritos de Lisboa e Setúbal). Ainda de acordo com as autoras, 10\% dos alunos dos distritos de Lisboa e Setúbal são imigrantes ou descendentes de imigrantes, enquanto nos distritos do interior Alentejano (Évora e Beja) apenas 1\% dos alunos são imigrantes ou descendentes de imigrantes. Estas percentagens revelam acentuadas assimetrias regionais na distribuição daqueles alunos no território português, evidenciando um poder de atracção ou repulsão regional diferenciado face às oportunidades de vida que apresentam e às expectativas de vida dos imigrantes e minorias étnicas.
Do ponto de vista da distribuição geográfica por nacionalidade, os distritos de Lisboa e Setúbal concentram grande parte dos alunos provenientes (e por ordem decrescente) dos PALOP, Índia/Paquistão e União Europeia; o distrito de Faro concentra maioritariamente alunos provenientes da União Europeia e dos PALOP; o distrito do Porto alunos provenientes da União Europeia, Brasil e Angola e, o distrito de Aveiro, alunos da União Europeia e do Brasil. Relativamente aos alunos de cultura cigana, os distritos com maior concentração, por ordem decrescente são os de: Lisboa, Setúbal, Porto, Faro, Bragança (interior Norte) e Aveiro.

De acordo com dados fornecidos pelo Secretariado Entreculturas para o ano lectivo de 1998/1999, 4 escolas do ensino básico concentravam mais de $70 \%$ de alunos imigrantes ou descendentes de imigrantes, 5 escolas mais de 60\%, 6 escolas mais de 50\%, 12 escolas mais de $40 \%$ e 23 escolas mais de $30 \%$. Grande parte destas escolas concentram-se na área Metropolitana de Lisboa. Estas concentrações de alunos por minorias não resultam, no entanto, de uma intencionalidade por parte do governo ou da organização da rede educativa, mas antes da inexistência de uma política urbana no que diz respeito à ocupação de espaços habitacionais, o que leva à concentração em bairros degradados de uma parte significativa de imigrantes oriundos dos PALOP ${ }^{17}$. Como em Portugal, para o Ensino Básico, existe a obrigatoriedade dos alunos se matricularem no estabelecimento de ensino da área de residência, este facto tem como consequência a concentração de alunos imigrantes e minorias étnicas em determinadas escolas, sendo esta uma das razões da existência de escolas com um número significativo de alunos provenientes de determinadas minorias.

\footnotetext{
17 Já no caso dos ciganos o processo é relativamente diferente dado por vezes existir uma intencionalidade por parte dos Presidentes de Câmara na concentração de elementos destas comunidades no mesmo espaço sócio-geográfico.
} 


\section{Migrantes, minorias e (in)sucesso escolar}

No que concerne aos níveis de sucesso e insucesso escolares, os alunos portugueses de cultura cigana, seguidos dos alunos cabo-verdianos são aqueles que apresentam taxas de insucesso mais elevadas nos três ciclos do ensino obrigatório (ver quadros 3, 4 e 5 em anexo) ${ }^{18}$. Com efeito, de acordo com os dados mais recentes, dentro dos PALOP, a minoria étnica cabo-verdiana é ainda aquela que apresenta as maiores taxas de insucesso escolar ao nível do ensino obrigatório no que diz respeito às crianças de minorias imigrantes ${ }^{19}$. Em termos das minorias globalmente consideradas, as crianças ciganas são aquelas que apresentam as mais baixas taxas de aprovação no ensino obrigatório ${ }^{20}$.

Algumas razões explicativas deste fenómeno parecem residir no facto destas minorias migrantes, por razões várias, nomeadamente de ordem cultural e de organização social maioria/minoria, se terem também transformado em minorias étnicas, lutando, de diferentes formas e de acordo com as suas próprias estratégias de (sobre)vivência, por um lugar, provisório porque mutável, na sociedade de "acoIhimento", conquistado e/ou cedido nas negociações e lutas desiguais entre gru- pos socioculturais com diferentes tipos e montantes de poder que originam oportunidades e modos de vida desiguais. As expectativas, percepções e interacções construídas entre diferentes grupos socioculturais influenciam activamente o lugar que cada grupo ou subgrupo migrante vai ocupar na sociedade, contribuindo diferenciadamente para a sua construção enquanto minoria étnica, não esquecendo que "a sedentarização dos imigrantes transforma [frequentemente] questões de imigração em questões de etnicidade" (MACHADO, 2002).

\section{Ciganos e (in)sucesso escolar: uma perspectiva analítica}

Relativamente ao ensino secundário, nível de ensino ao qual chega um número muito reduzido de alunos ciganos, de 1994/ 95 a 1997/98 assistiu-se a uma mudança significativa nos níveis de aproveitamento escolar destes alunos, passando de $0 \%$ de aprovações no ano lectivo de 1994/95, para 100\% de aprovações nos anos lectivos de 1996/97 e 1997/98 (ver quadro 6 em anexo $)^{21}$. Estes níveis de sucesso parecem revelar uma mudança de atitude em relação à escola e aos saberes escolares por parte das famílias e dos alunos que chegam a este nível de ensino, para quem a escola começa a aparecer como uma forma de mudança e elevação do estatuto social. ${ }^{22}$

\footnotetext{
${ }^{18}$ A propósito das razões do insucesso escolar dos alunos ciganos, ver Maria José Casa-Nova (2002, 2003 e 2004b).

${ }^{19}$ Estes níveis de insucesso mais elevados podem estar parcialmente relacionados com o facto da Língua Cabo-verdiana - o Crioulo de raiz portuguesa - ter na sua constituição palavras com grafia igual à Língua Portuguesa, mas com uma semântica diferente, induzindo nos alunos uma falsa compreensão do Português e, consequentemente, dos conteúdos curriculares.

${ }^{20}$ Saliente-se que, no ano lectivo de 1997/98, para o $1^{\circ}$ ciclo do ensino básico, de 5420 alunos ciganos matriculados nos quatro anos de escolaridade, foram sujeitos a avaliação no $4^{\circ}$ ano 764 alunos, dos quais foram aprovados $55 \%$; para o $2^{\circ}$ ciclo, de 374 alunos matriculados nos dois anos de escolaridade, foram sujeitos a avaliação no final do ciclo $\left(6^{\circ}\right.$ ano $) 85$ alunos, dos quais foram aprovados $75 \%$; para o $3^{\circ}$ ciclo, de 102 alunos matriculados nos três anos de escolaridade, foram sujeitos a avaliação no final do ciclo $\left(9^{\circ}\right.$ ano) 11 alunos, dos quais ficaram aprovados $64 \%$.

${ }^{21}$ Neste nível de ensino, no ano lectivo de 1997/98, estavam matriculados apenas 16 alunos, dos quais 4 foram sujeitos a avaliação no $12^{\circ}$ ano, tendo todos concluído o ano em questão.

${ }^{22}$ A este propósito, ver Maria José Casa-Nova (2002).
} 
De facto, no que concerne à minoria étnica cigana, uma investigação por nós realizada entre 1997 e 1999 (CASA-NOVA, 1999, 2002), à qual estamos a dar continuidade desde 2002, permitiu-nos concluir pela existência de graus de importância diferenciados atribuídos à escola (bem como diferentes formas de perspectivar a entrada no mercado de trabalho e a relação com a sociedade no seu todo). Esta evidência empírica levou-nos à construção do conceito de "lugares de et-

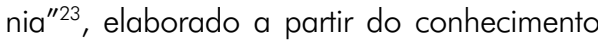
de uma diferenciação intra-étnica, tendo por base uma auto-diferenciação realizada pelos diferentes sujeitos-actores, constituindo-se em lugares intermédios (não necessariamente hierarquizáveis ou hierarquizantes) dentro do que designámos, já em 1999, como habitus étnico (CASA-NOVA, 1999, 2002, 2004b). Estes lugares de etnia, construídos nomeadamente a partir da existência de diferentes graus de consciencialização étnica dentro deste grupo, originam reconfigurações do habitus primário e permitem compreender as heterogeneidades e homogeneidades encontradas, nomeadamente em relação à forma de perspectivar os saberes escolares, onde a atribuição de uma maior ou menor significado à escola não parece estar dependente da posse de maiores recursos económicos (estas famílias são, aliás, aquelas que menor significado atribuíam aos saberes escolares). Estes lugares de etnia constituem-se em lugares móveis em função quer das dinâmicas, da diversidade de estratégias e expectativas de vida, das percepções de si e do outro e das redes de sociabilidade desenvolvidas, quer dos contextos locais, nacionais e supranacionais.

No que diz respeito à escola, a passagem de um lugar de etnia a outro é influ- enciada, por exemplo, por expectativas de vida diferenciadas, pelo lugar atribuído à escola no jogo das oportunidades de vida, pela maior ou menor permeabilidade das famílias e dos indivíduos às pressões grupais e comunitárias, pela discordância individual ou grupal com alguns dos valores da chamada "Lei Cigana", pelo apoio comunitário relativo a uma mobilidade social - horizontal ou vertical ascendente - de alguns dos seus elementos e pelo papel da escola na relação com a diferença cultural.) Podem ainda resultar de uma maior ou menor afirmação identitária, de etnicidades mais ou menos contrastantes com a sociedade global, sendo que, uma maior valorização da escola pode não significar uma menor afirmação étnica. Esta diversidade de situações poderá coexistir dentro de uma mesma comunidade, variando as mesmas em função dos contextos, estratégias e interesses individuais e grupais.

É a variedade e a variabilidade destas situações que procurámos tornar visível no gráfico 1 (onde L1 significa lugar de etnia 1, L2 lugar de etnia 2 e L3 lugar de etnia 3).

\section{Gráfico 1}

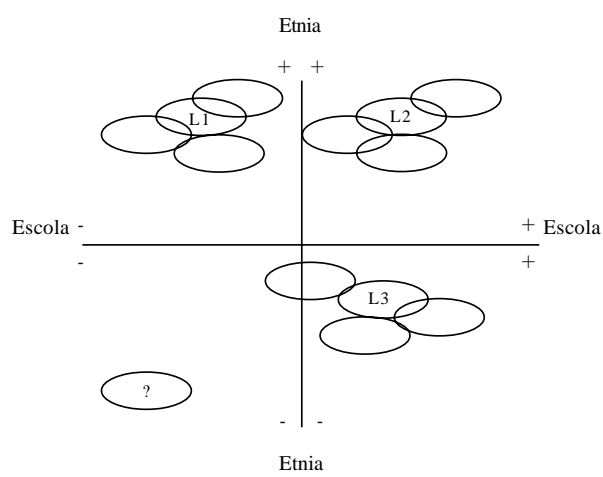

${ }^{23}$ CASA-NOVA, 1999, 2002 
No que diz respeito aos ciganos, a maioria dos seus elementos situa-se ainda no quadrante mais etnicidade e menos escola. De facto, do ponto de vista da socialização e educação familiares, as crianças desenvolvem-se num ambiente familiar e comunitário pouco sensível (embora não hostil) à escola, onde esta aparece com uma importância relativamente residual face às restantes actividades do seu quotidiano. Não é que as famílias e crianças ciganas não gostem, não considerem importante ou resistam à escola; é que esta ainda não foi considerada como suficientemente significativa (embora possa ter sido percebida enquanto tal) para, de forma durável e não episódica, fazer parte dos seus projectos e quotidianos de vida. $\bigcirc$ ritmo de vida das crianças é pautado pelo ritmo de vida dos adultos, as suas formas de vivência do quotidiano são pautadas pelas formas e conteúdos de vivência do quotidiano dos adultos, ou seja, ao nível do ritmo das feiras, das festas, das horas para dormir, das redes de sociabilidade [...]. Estes e outros factores influenciam as formas de percepção espacial e temporal, organização mental e estruturação de pensamento das crianças, processando-se estas de maneira diferente daquela que é exigida pela escola tal como esta se encontra actualmente configurada.

Saliente-se ainda que a existência de uma maior valorização escolar pode traduzir-se numa frequência escolar prolongada e na aquisição de certificados escolares mais elevados ou traduzir-se numa não frequência escolar, dependendo das estratégias e oportunidades de vida familiares e grupais. Ou seja, existindo famílias que valorizam igualmente os saberes escolares, algumas conseguem que os seus filhos frequentem a escola de forma prolongada, enquanto ou- tras, seja por razões de sobrevivência económica, seja por razões de género (ou outras), não conseguem manter os seus filhos na escola.

$\mathrm{Na}$ investigação que estamos a realizar não foi visibilizada qualquer situação de fraca etnicidade e fraca valorização escolar, colocando-se a possibilidade deste lugar de etnia por relação à escola ser eventualmente visível em outras comunidades ciganas. Sendo este quadro analítico construído a partir da etnicidade cigana, o mesmo poderá ser visível em outras minorias migrantes, faltando no entanto, investigações neste domínio.

No que diz respeito aos alunos cabo-verdianos, os níveis de aproveitamento no ensino secundário e para o ano lectivo de 1997/98, estão relativamente próximos dos níveis de aproveitamento dos alunos de outras proveniências, o que pode significar, por um lado, que estas famílias se mobilizam em torno de uma estratégia de melhoria das condições de vida dos seus descendentes (através da construção de percursos escolares de êxito) ${ }^{24}$, derivando daqui uma maior assimilação das normas e conteúdos da cultura oficial escolar e, por outro, que a selectividade inerente ao reduzido número de alunos que conseguem terminar o ensino secundário evidencia que só os mais aptos conseguiram sobreviver dentro do sistema de ensino. ${ }^{25}$

\section{Escola e diversidade cultural: trabalhar com a diferença}

Esta questão conduz-nos à problematização de como é trabalhada a diferença ao nível da escola e da sala de aula, sendo sobre esta questão que iremos reflectir seguidamente

\footnotetext{
${ }^{24}$ A propósito das estratégias de famílias cabo-verdianas em relação à escola e tendo em atenção a classe social de pertença, ver Teresa Seabra (1999).

${ }^{25}$ Saliente-se que, apesar do número de alunos cabo-verdianos matriculados nos três anos do Ensino Secundário para o ano lectivo de 1997/98, ser de 921, o número de alunos que se sujeitaram à avaliação no último ano do Ensino Secundário (12ªno) foi de 108, dos quais $62 \%$ terminaram com sucesso (Cf. SEABRA; MATEUS, 2003).
} 
através da abordagem de uma investigação específica. Mas antes de entrarmos nesta discussão, gostaríamos de clarificar o que entendemos por educação inter/multicultural:

Quando falamos em educação inter/ multicultural queremos com esta expressão significar uma educação que contemple a diversidade cultural em termos de classes sociais, etnias e géneros e, dentro de cada uma destas categorias, a diversidade proveniente das particularidades culturais e de formas de apropriação individuais dos saberes escolares e não escolares, de contextos e de processos. Esta educação intercultural deverá, então, no nosso entender, ter subjacente uma 'abordagem não-sincrónica' (McCARTHY, 1994), que nos sugere a possibilidade de os grupos minoritários, na sua relação e interacção com instituições económicas, políticas e culturais, não revelarem sempre a mesma postura, necessidades, interesses ou expectativas, sendo portanto fundamental deixarmos de olhar e tratar cada classe social, etnia ou género como blocos homogéneos, uniformes, mas antes como entidades culturais cujas relações sociais são complexas, contraditórias e não paralelas (CASA-NOVA, 2002, p. 110).

Isto significa que, apesar de neste trabalho enfatizarmos a vertente étnico-cultural da educação intercultural, numa análise global desta problemática, as vertentes de classe e género não podem ser negligenciadas dado constituírem importantes dimensões da (des)igualdade escolar e da construção de oportunidades de vida diversificadas. E se, ao nível das investigações realizadas tendo em atenção a relação classe social de pertença-(in)sucesso escolar e discriminação escolar por relação ao género, os estudos existentes em Portugal remontam já às décadas de 70 e 80 do século $X X^{26}$, em termos das investigações relativas a minorias étnicas e escolaridade só a partir de meados da década de 90 é que podemos considerar a produção de perspectivas analíticas ${ }^{27}$

\footnotetext{
${ }^{26}$ Não sendo possível abordar aqui estas dimensões, não queremos deixar de referenciar alguns trabalhos realizados neste domínio. Assim, sobre a relação classe social de pertença-(in)sucesso escolar ver, entre outros, os trabalhos de Ana Benavente (1990), Ana Benavente e Adelaide Pinto Correia (1981), Ana Benavente e outros (1994), Almerindo Afonso (1987), Helena Araújo (1987), Licínio Lima (1987), João Formosinho (1987), Sérgio Grácio e Sacuntala de Miranda (1977) e Raul lturra (1990a, 1990b). Sobre discriminação escolar por relação ao género ver, entre outros, os trabalhos de Helena Araújo (1998, 2001, 2002), onde a autora elabora uma interessante síntese dos trabalhos considerados mais significativos no campo do género e educação em Portugal. Ver também os trabalhos de Isabel Barreno (1985), Anne Marie Fontaine (1977), Fernanda Henriques (1994), Laura Fonseca (2001) e Ana Maria Ferreira (2002).

${ }^{27}$ Fazendo apenas referência a artigos escritos por investigadores/as portugueses/as em publicações periódicas portuguesas, e considerando o período de tempo entre 1987 e 2001, uma recolha não exaustiva permitiu concluir que entre 1987 e 1991 foram publicados 9 artigos, entre 1992 e 1996 foram publicados 54 artigos e, entre 1997 e 2001 foram publicados 63 artigos sobre esta problemática, totalizando 126 publicações (Cf. CORTESÃO et al., 2002), não se incluindo aqui os artigos publicados em revistas estrangeiras e que, numa recolha não exaustiva para o mesmo período de tempo, totalizam 25. Saliente-se que entre 1987 e 1990 apenas foi publicado um artigo (GOMES, 1987) intitulado "A interacção selectiva na escola de massas" onde, apesar do autor não fazer referência explícita à problemática da educação intercultural, estão subjacentes alguns princípios norteadores da construção de uma educação intercultural. Daquelas 126 publicações, aproximadamente metade são referenciáveis à educação e diversidade cultural. Os primeiros artigos revelavam fundamentalmente uma precupação com a definição de conceitos (multiculturalismo, educação intercultural, identidade cultural, etnia, etnicidade, assimilação, integração [...]), tendo-se progressivamente assistido a uma complexificação das análises produzidas, problematizando a influência dos contextos internacionais na construção das políticas educativas públicas nacionais, a construção curricular, a formação de professores para a diversidade cultural, a cultura familiar e a cultura escolar, o Português como Língua materna e como Língua segunda, a interacção pedagógica na sala de aula, a construção de dispositivos pedagógicos [...]. A outra metade das publicações é genericamente referenciável à construção multicultural da sociedade portuguesa, problematizando o racismo no quotidiano dos migrantes, a construção identitária e a integração social das chamadas "segundas gerações" (apesar de frequentemente se considerar acriticamente como "segunda geração" os descendentes de imigrantes nascidos em Portugal, salientamos que, na nossa perspectiva, as segundas gerações deverão ser definidas a partir da percepção que os jovens têm de si, ou seja a partir de uma auto-definição em termos de referência cultural e identitária e não de uma exterioridade analítica). A inclusão/exclusão social dos migrantes e a construção das etnicidades são outras das problemáticas objecto de análise.
} 
que, tendo sido produzidas a partir da realização de projectos de investigação com origem nas Universidades, se constituem actualmente num quadro teórico de referência e ponto de partida para o desenvolvimento de novas investigações neste domínio. ${ }^{28}$

\section{O exemplo de uma investigação}

Não sendo possível referenciar aqui os resultados das diversas investigações realizadas, iremos reportar a nossa análise a uma investigação que levámos a cabo entre 1997 e 1999 numa escola dos $1^{\circ}$ e $2^{\circ}$ ciclos do Ensino Básico ${ }^{29}$ da periferia da cidade do Porto (Norte de Portugal), onde alguns dos quadros teóricos produzidos serviram de referência analítica e cujos resultados do ponto de vista das práticas profissionais docentes procuraremos aqui sumariar. ${ }^{30}$

Do ponto de vista da escola, esta investigação teve como objectivos "analisar o papel da escola e os contextos e processos que dão forma e conteúdo às práticas pedagógicas das professoras, através do conhecimento e compreensão das respostas desta escola à diversidade do seu público" (CASA-NOVA, 2002).

Um dos primeiros aspectos que gostaríamos de salientar relaciona-se com a forma de estar daquelas professoras na profissão e naquela escola específica, que se revelou ser influenciada pelas suas expectativas face à realidade sócio-económico-cultural dos agregados familiares de origem das crianças que frequentam a escola e pela forma como cada professora reflecte e interioriza essa realidade. Esta forma é atravessada pela percepção do papel que desempenham socialmente e que se reflecte na construção de práticas pedagógicas que promovem a vertente da instrução mas, e sobretudo, a vertente da socialização em normas e valores da chamada cultura oficial, tendo sido notório uma baixa pressão sobre os alunos para a aprendizagem e rendimento escolares.

Os discursos e práticas observados são reveladores de uma outra dimensão da reprodução cultural e social:

$\bigcirc$ insucesso e a exclusão escolares

\footnotetext{
${ }^{28}$ Apesar de na década de 90 terem sido desenvolvidos vários projectos de investigação neste domínio, queremos salientar aqui o desenvolvimento do Projecto de Educação e Diversidade Cultural: para uma sinergia de efeitos de investigação, levado a cabo por iniciativa de um grupo de professores/as e investigadores/as da Faculdade de Psicologia e de Ciências da Educação da Universidade do Porto, entre os quais se incluía a autora deste artigo, então como bolseira de investigação. Este projecto, coordenado por Stephen Stoer e Luiza Cortesão, teve uma duração de 4 anos (de 1991 a 1994) e englobou três escolas do $1^{\circ}$ ciclo (duas no distrito do Porto e uma no distrito de Lisboa, frequentadas por uma população heterogénea do ponto de vista cultural, mas relativamente homogénea do ponto de vista da pertença de classe) e uma escola dos $2^{\circ}$ e $3^{\circ}$ ciclos do Ensino Básico inserida num contexto semi-rural do distrito de Braga. Era preocupação da equipa de investigação "[...] a construção e o desenvolvimento da escola para todos [...] uma escola onde as crianças e jovens de diferentes grupos «minoritários» adquiram saberes e instrumentos que os ajudem a viver e intervir numa sociedade hegemónica sem que isso seja conseguido através da destruição da auto-imagem e da cultura do seu grupo de pertença" (CORTESÃO; STOER, 1995). Cremos poder afirmar que, pelo processo reflexivo que despoletou, o ponto de viragem fundamental em termos da maturação e produção teóricas neste domínio em Portugal foi a elaboração e desenvolvimento deste Projecto, que esteve na origem de opções investigativas de vários membros da equipa e produções teóricas subsequentes. Ver, a título de exemplo, Luíza Cortesão e Natércia Pacheco (1991); Stephen Stoer (1992, 1994, 2001); Cortesão e outros (1995); Carlinda Leite (1996, 2002a e 2002b); Natércia Pacheco (1996); Luiza Cortesão (2001); Luiza Cortesão e Stephen Stoer (1996, 1997, 1999, 2001) e Casa-Nova (2001 a, 2001 b, 2002, 2003a, 2003b, 2004a, 2004b). Alguns trabalhos que receberam a influência deste projecto: Ricardo Vieira (1995, 1999); Pedro Silva (1993, 1996, 2003).

${ }^{29}$ Primeiros seis anos de escolaridade.

${ }^{30} \mathrm{~A}$ escola estudada era frequentada por um público culturalmente heterogéneo, mas homogéneo no que diz respeito à classe social de pertença, coexistindo alunos luso-descendentes, ciganos, cabo-verdianos e angolanos. Nesta investigação, a investigadora constituiu-se no principal instrumento de pesquisa, realizando observação participante em sala de aula e entrevistas semiestruturadas a diversos/as professores/as da escola.
} 
não se dão somente pela imposição arbitrária de um conhecimento expresso no código dominante, mas também porque a crianças de classes sociais e minorias étnicas desfavorecidas se nega o acesso à cultura dominante através, por um lado, da diminuição do nível de exigência na distribuição e apropriação do saber considerado socialmente válido e escolarmente ensinado (BOURDIEU; PASSERON, 1972)

e, por outro lado, "pela negação da possibilidade de (re)construção desse saber com as crianças" (SILVA, 1988; CASANOVA, 2002, 2003). As professoras revelaram, a nível discursivo e a nível prático, alguma preocupação com a existência de públicos escolares étnica e culturalmente diferenciados, mas essa preocupação não se traduzia, na sua maioria, num aproveitamento efectivo da cultura de cada criança ao nível do desenvolvimento de práticas pedagógicas contextualizadas (mas exigentes) e interculturais, desenvolvendo fundamentalmente "práticas pedagógicas homogéneas e homogeneizantes" (CASA-NOVA, 2002), próximas do que Enguita (1996) designou de "forma carencial de abordar a diferença", apoiadas na convicção de que as crianças necessitam de ser compensadas dos conhecimentos e valores que não
Ihes são transmitidos na sua cultura de origem. No entanto, foram também visíveis esforços e práticas que denotam uma consciencialização ao nível da necessidade de se atender positivamente à diferença cultural; alguns discursos e práticas reveladores de alguma preocupação com as especificidades culturais e as especificidades do modelo de socialização escolar. Consideramos no entanto que a educação/ensino ministrados naquela escola insere-se maioritariamente num modelo monocultural (que resulta grandemente da incapacidade de trabalhar com a diferença cultural e não de uma recusa em trabalhar com a mesma) e não num modelo de educação inter/ multicultural crítica, entendida como uma educação que, por um lado, desenvolva práticas pedagógicas contextualizadas, através da elaboração de "dispositivos pedagógicos" que permitam o acesso a um "bilinguismo cultural" (CORTESÃO; STOER, 1996) $)^{31}$. A percepção das professoras da prática da educação inter/multicultural era grandemente a do desenvolvimento de actividades fora do espaço da sala de aula, actividades extra-curriculares, materializadas em danças, cantares e semanas gastronómicas das diversas culturas, dando origem a um "pluralismo cultural benígno"32 que dificilmente se traduz em resultados académicos positivos ou em oportunidades de vida diversificadas.

\footnotetext{
${ }^{31}$ Por "dispositivos pedagógicos" (e sem prejuízo de outras significações que os/as autores/as possam atribuir futuramente a estes conceitos) os/as autores/as entendem o desenvolvimento de práticas pedagógicas contextualizadas, que trabalhem positivamente com a diferença cultural, rentabilizando-a no processo de ensino-aprendizagem. Por "bilinguismo cultural" é entendido o domínio, por parte dos alunos, da cultura de origem e da cultura da escola, procurando estabelecer uma linha de continuidade entre os códigos culturais familiares e os códigos da cultura oficial veiculada pela escola, promovendo a cultura de origem da criança, mas possibilitando-Ihe simultaneamente o acesso a e o domínio de códigos culturais socialmente valorizados.

32 De acordo com Stoer (1999), o "pluralismo cultural benígno" rege-se por actos de reconhecimento muito mais do que por actos de conhecimento cultural e caracteriza-se por "assumir automaticamente a diferença como positiva (cai-se num relativismo cultural chique e piedoso pouco problematizado e reflectido); por se admitir que basta a formação de uma atitude multicultural entre os professores para garantir a mudança educativa (desenvolve-se a retórica da educação multicultural); enfatiza-se 'estilos de vida' relegando para segundo lugar 'oportunidades de vida' (elogia-se a tolerância em vez de promover a justiça social); desenvolvese estratégias para a educação intercultural num aparente vácuo social e político assim produzindo meras técnicas descontextualizadas (desvirtua-se a educação intercultural divorciando-se da construção da sociedade multicultural)."
} 
Apesar das práticas pedagógicas monoculturais serem predominantes, queremos sublinhar que, neste olhar sobre uma escola, o que se revelou mais interessante do ponto de vista das possibilidades de conhecimento e compreensão de uma dada realidade e, consequentemente, das possibilidades de construção de conhecimento, foi desvelar e compreender a complexidade, pluralidade e simultaneidade de perfis pessoaisprofissionais de professores e de professoras que revelaram características que apontam para a possibilidade de estarmos em presença de práticas e de discursos pedagógicas que sustentam diferentes concepções de escola:

- observamos e ouvimos práticas e discursos que revelaram uma percepção das crianças como "sistemas deficitários", que não possuem as competências necessárias para aceder ao conhecimento escolarmente transmitido, o que configuraria um/a professor/a anterior à construção da actual escola de massas, que designámos por escola de domesticação - professor/a pré/monocultural.

- Nesta realidade escolar coexiste o/a professor/a que acredita que todas as crianças devem ter acesso à escola, olhando o seu público escolar como contendo um potencial para a apreensão da cultura escolar: ০/a professor/a da escola de massas - escola meri- tocrática, professor/a monocultural ${ }^{33}$ mas desenvolvendo práticas pedagógicas maioritariamente homogéneas e homogeneizantes.

- Encontrámos também o/a professor/a que reconhece a existência na escola de uma multiplicidade de culturas, mas dando visibilidade às diferenças culturais numa perspectiva de "folclorização" das mesmas, o que designámos por professor/a mono/multicultural - e por escola essencialista-diferencialista.

- A observação realizada desocultou ainda dilemas de professores/as que, tendo consciência das desigualdades sociais e escolares existentes e acreditando na possibilidade de democratização do processo de ensino-aprendizagem, procuram promover práticas pedagógicas sensíveis à diferença cultural, aproximando-se do tipo-ideal de professor/a inter/multicultural de uma escola cidadã, deparando-se contudo com constrangimentos exteriores a si, que dificultam a implementação de tais práticas. ${ }^{34}$

Face a esta realidade complexa e extraordinariamente rica do ponto de vista dos significados, consideramos que "da crise e consolidação da escola de massas" (STOER; ARAÚJO, 1992) que se vive actualmente em Portugal ${ }^{35}$ resultam professores/as dos/

\footnotetext{
${ }^{33}$ Num artigo intitulado "Construindo a escola democrática através do "campo da recontextualização pedagógica»", Stoer (1994) problematiza a construção de tipos-ideais de professor/a: "o/a professor/a monocultural" e "o/a professor/a inter/multicultural", que procuram configurar diferentes formas de olhar a e trabalhar com a diferença em função das estruturas e das dinâmicas sociais. O tipo-ideal de professor/a monocultural é aquele que nas suas práticas pedagógicas não considera a diversidade de culturas presentes na sala de aula, pelo facto de frequentemente apenas 'reconhecer' a existência de diferenças culturais e raramente as procurar 'conhecer'. Este professor ou professora é defensor de uma escola meritocrática, "considera importante a homogeneidade cultural na sala de aula, veiculando a cultura nacional na escola oficial para todos." Em oposição a este tipoideal de professor/a Stoer propõe a construção de professores/as inter/multiculturais, defensores de uma escola democrática e de uma democracia participativa, capazes de introduzir o "ruído da multidimensionalidade" (McCARTHY, 1994) através da construção de "dispositivos pedagógicos" que possibilitem trabalhar na sala de aula, numa perspectiva valorativa positiva, a cultura familiar de cada criança e jovem. Será este tipo de professor/a que protagonizará algumas das mudanças necessárias para a construção de sociedades mais igualitárias, inclusivas da diferença cultural.

${ }^{34}$ Para uma melhor compreensão e aprofundamento deste quadro teórico, ver Casa-Nova (2001a, 2002).

35 Crise e consolidação que, de acordo com os/as autores/as, por um lado deriva do aumento gradual da duração da escolaridade obrigatória e, por outro, da incapacidade da escola de massas resolver a questão da desigualdade social e cultural, ao mesmo tempo que promove, no seu interior, essa mesma desigualdade (Cf. BOURDIEU; CHAMPAGNE, 1997).
} 
as quais emergem simultaneamente características que configuram perfis pessoaisprofissionais que designámos de pré/mono/ multi/interculturais (ou seja, professores/as que apresentam características dos quatro tipos anteriormente apresentados).

As práticas e os discursos observados e escutados foram reveladores de comportamentos e discursos que parecem indiciar estarmos em presença de um corpo docente que, face ao processo de construção da escola de massas, se encontra num processo de (re)construção do seu próprio caminho, resultando daqui a simultaneidade de características onde os paradoxos, as (aparentes) incoerências, as perplexidades, o reconheci- mento e a tentativa de conhecimento da diversidade cultural se entrecruzam e interpenetram, dando origem a práticas pedagógicas e discursos aparentemente contraditórios, coexistido num/a mesmo/a docente formas diversificadas de ser professor/a.

gráfico 2 procura ser revelador desta complexidade, onde o tamanho e a tonalidade das elipses pretende significar a gradatividade do tipo de escola e de professor/a encontrados nesta investigação quanto maior e mais escura, mais visível é o tipo de escola e de professor/a. A área de intercepção dos quatro tipos encontrados pretende significar a coexistência e a simultaneidade da sua realização.

\section{Gráfico 2}

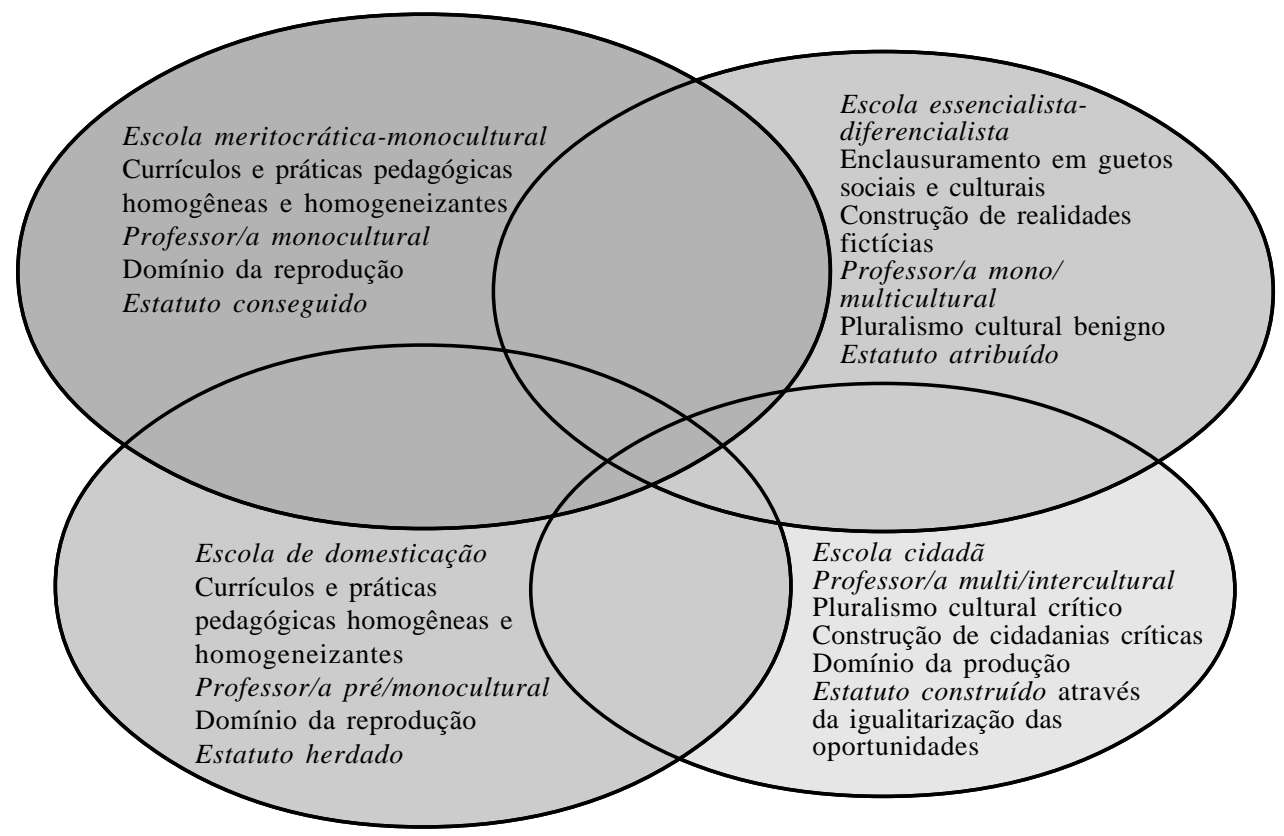

Ensaio: aval. pol. públ. Educ., Rio de Janeiro, v.13, n.47, p. 181-216, abr.jun. 2005 
Sem prejuízo da existência ou da emergência de outras formações escolares e de outros perfis pessoais-profissionais docentes para além das quatro detectadas nesta investigação (e de uma quinta que resultaria da simultaneidade de realização daquelas quatro), cremos que o que importa aqui salientar é a pluralidade e complexidade de situações que apontam para professores/as e práticas profissionais que evidenciam o que consideramos "uma 'não-sincronia' interna ao próprio sujeito-actor, já não aplicável apenas a grupos ou categorias sociais, mas também a sujeitos-actores individuais" (CASA-NOVA, 2002). Estes perfis pessoaisprofissionais configuram identidades complexas, constituídas por uma multiplicidade de pertenças (étnicas, de classe, de gênero, ideológicas, geracionais [...]), identidades que originam comportamentos "não sincrônicos" em função dos contextos e das dinâmicas sociais e culturais.

\section{Políticas sociais e educativas públicas, imigrantes e minorias étnicas $^{36}$}

Também do ponto de vista governamental, só muito tardiamente (no início da década de 90 do século XX) se assistiu em Portugal à criação de organismos sob tutelas ministeriais, com o objectivo de trabaIhar com a diversidade cultural, procurando principalmente resolver e prevenir problemas resultantes da interacção das minorias com as diversas instituições portuguesas e com a sociedade no seu todo, mas também ter alguma atenção à diferença cultural.

primeiro organismo foi criado em 1991 e designava-se Secretariado Coordenador dos Programas de Educação Multicultural, apresentando na altura competências estritamente de âmbito educativo ${ }^{37}$. Este organismo é responsável, entre outras coisas, pela recolha e tratamento dos dados relativos ao sucesso e insucesso escolares de todos os alunos que frequentam os ensinos básico e secundário em Portugal. Tem produzido vários manuais (e outros materiais) de apoio pedagógico na sala de aula, embora alguns desses manuais por vezes apresentem e transmitam imagens estereotipadas de minorias, nomeadamente no que diz respeito aos ciganos. $O$ seu objectivo principal consistia em procurar compreender e diminuir as razões do insucesso escolar que determinadas minorias apresentavam ao nível do $1^{\circ}$ Ciclo do Ensino Bási$\mathrm{co}$, principalmente as minorias cabo-verdiana (uma minoria exógena, resultante de processos imigratórios) e cigana (uma minoria endógena à sociedade portuguesa). A principal iniciativa deste organismo consistiu no desenvolvimento de um projecto, - "Projecto de Educação Intercultural"38, com início em 1993 e termo em 1997 tendo, para o efeito, seleccionado um conjunto de escolas do $1^{\circ} \mathrm{Ciclo}$ (num total de 52: 30 escolas na primeira fase de 199395, alargado a mais 22 escolas na segunda fase, de 1995 a 1997), maioritariamente da zona de Lisboa, frequentadas fundamentalmente por minorias étnicas que apresentavam elevadas taxas de insucesso es-

\footnotetext{
${ }^{36}$ As políticas e medidas legislativas aqui referenciadas, são o resultado de uma selecção realizada pela autora após pesquisa nesta área, não tendo um carácter de exaustividade, mas antes de significado, tendo em atenção procurar compreender em que medida as políticas e medidas legislativas dos governos portugueses revelam uma preocupação com a diferença cultural.

${ }^{37}$ Despacho Normativo n 63/91, de 13 de Março, sob dependência do Ministério da Educação.

${ }^{38}$ Despacho n ${ }^{\circ} 170 / \mathrm{ME} / 93$ e 78/ME/95.
} 
colar. No sentido de procurar diminuir as taxas de reprovação, elegeram-se algumas áreas de intervenção que passaram pela caracterização sociocultural da população escolar, pela constituição de equipas multidisciplinares para reflexão e actuação sobre os problemas encontrados, pela construção de materiais pedagógicos específicos e pelo desenvolvimento de acções de formação para professores no domínio da educação intercultural ${ }^{39}$.

No entanto, um dos problemas encontrados e que obstaculizou parcialmente o êxito do projecto, derivou da existência de elevadas carências económicas detectadas pelas equipas no terreno (com repercussões ao nível da alimentação das crianças, que se revelou muito deficitária), levando as equipas a procurar minorar, em primeira instância, os problemas de carácter económico. ${ }^{40}$

Podemos considerar que, no que concerne à atenção à diferença cultural, a construção deste organismo se constituiu na primeira medida de discriminação positiva levada a cabo pelo Governo, embora não se tenha revelado eficaz no combate ao insucesso escolar. A este facto não foi alheio (para além das carências económicas acima mencionadas), o tratamento da diferença cultural na base de estereótipos e não num conhecimento aproximado das diversas culturas em presença, bem como uma actuação baseada no pressuposto de que cada etnia constitui um bloco homogéneo, uniforme, negligenciando-se as suas diferenciações internas.

Como Almerindo Afonso (1999) refere, podemos "considerar os Programas de Educação Multicultural [...] como medidas genericamente referenciáveis à actuação do Estado-Providência", embora "a contribuição destes Programas [tenha sido] importante mas simultaneamente frágil quando pensada em termos da concretização do princípio da igualdade de oportunidades e da expansão dos direitos sociais e culturais", podendo significar a expansão de um Semi-Estado Providência, mas não a construção de um Estado-Providência. ${ }^{41}$

Este Secretariado foi substituído, em 2001, pelo Secretariado Entreculturas ${ }^{42}$, assistindose a uma alargamento de competências, nomeadamente ao nível da colaboração na definição e dinamização de políticas activas de combate à exclusão no que diz respeito à sociedade em geral e já não somente à escola. Em Janeiro de 2004 este Secretariado foi incorporado no Alto Comissariado para a Imigração e Minorias Étnicas.

Ainda do ponto de vista da educação escolar, em 1996 foi elaborado um Despacho relativo à criação e implementação de Currículos Alternativos $^{43}$ no Ensino Básico, com o objectivo de diminuir o abandono e o insu-

\footnotetext{
39 Para uma análise exaustiva e crítica da implementação e resultados deste projecto, ver Carlinda Leite (2002a).

${ }^{40}$ Esta experiência, tendo-se revelado relativamente positiva, não foi, no entanto alargada a todas as escolas do país como tinha sido inicialmente anunciado.

${ }^{41}$ Apesar de conscientes da influência dos processos de globalização e da entrada de Portugal na União Européia na construção destas políticas, por falta de espaço estas dimensões não serão aqui objecto de análise. Também pela mesma razão não procederemos à análise da ideologia subjacente às diferentes formações partidárias que se constituíram em governo desde 1990 até à actualidade (desde um Governo de Centro - PSD, a um Governo Socialista - PS e a um Governo de Centro-Direita - PSD/ CDS), que originaram políticas de pendor mais democrático ou de pendor mais neo-liberal e neo-conservador, embora esta análise deva ser complexificada pela conjuntura económica internacional inerente a cada período governativo.

${ }^{42}$ Despacho Normativo n ${ }^{\circ} 5 / 2001$, de 1 de Fevereiro.

${ }^{43}$ Despacho n ${ }^{\circ} 22 / \mathrm{SEEI} / 96$, de 19 de Junho.
} 
cesso escolares, fundamentalmente ao nível do $3^{\circ}$ Ciclo $\left(7^{\circ}, 8^{\circ}\right.$ e $9^{\circ}$ anos de escolaridade). Estes Currículos Alternativos, de acordo com o discurso oficial, tinham como objectivo levar um maior número de jovens a permanecer no sistema educativo e a terminar com sucesso a escolaridade obrigatória, parecendo contribuir para a inclusão no sistema educativo de jovens que tradicionalmente estariam dele excluídos por repetidos insucessos no currículo nacional. No entanto, com a implementação deste diploma, estes alunos passaram a estar inseridos no sistema educativo (e não integrados uma vez que não são bem sucedidos no currículo nacional) baseado num sistema de desigualdade dado que, "a designação 'currículos alternativos' e não 'currículos equivalentes', já indicia uma subalternidade em relação a um currículo-padrão" (CASA-NOVA, 2002 , p. 135). A sua elaboração e implementação, ao eliminar do leque de disciplinas a frequentar pelos alunos, disciplinas como a Língua Portuguesa e a Matemática, torna-se impeditivo, na prática, da construção de um percurso escolar de sucesso no que diz respeito ao prosseguimento de estudos por estes alunos. $E$ dado que os jovens que frequentam estes currículos são jovens pertencentes a classes sociais e minorias étnicas desfavorecidas, o ensino para o aluno-padrão, o "aluno-ide$a^{\prime}$ ", não se altera, "o que muda é a «via» pela qual os estudantes são «dimensionados» para a chamada «vida activa» (STOER, 1994), perpetuando-se assim a desigualdade sob a capa de uma discriminação positiva.

Também em 1996, o Despacho 147/B/ME/ 96 cria os TEIP - Territórios Educativos de Intervenção Prioritária (semelhante às ZEP francesas) que, logo no seu preâmbulo, justificava o seu aparecimento pelo reduzido sucesso educativo "em zonas com número significativo de alunos de diferentes etnias, filhos de imigrantes ou filhos de populações itinerantes". No entanto, nos seus objectivos e restante articulado, não é feita qualquer referência à necessidade de se desenvolver uma educação intercultural nas escolas abrangidas, referindo que com esta medida se pretende: "contribuir para a descentralização de políticas educativas; aproximar a escola da comunidade educativa e do meio; rentabilizar os recursos locais, através da partilha e da construção de parcerias; promover o sucesso educativo, favorecendo a articulação entre os diferentes ciclos de ensino". Não existe portanto neste Despacho qualquer "referência explícita à educação intercultural", apesar de "dos 148 estabelecimentos de ensino integrados nos 34 TEIP, definidos para o ano lectivo de 1996/97, 27 fazerem parte da rede do Projecto de Educação Intercultural" (SOUTA, 1997, p. 68), o que torna esta ausência ainda mais paradoxal. Saliente-se também o facto da caracterização dos TEIP se ter feito sempre pela abordagem negativa das situações familiares dos alunos e dos próprios alunos (ou seja, a partir do que thes faltava) e nunca pelas potencialidades que poderiam conter. ${ }^{44}$ Constituindo-se numa medida de discriminação positiva, pela maior afectação de recursos (nomeadamente monetários) e de pessoas, não possuía no entanto como fundamento ideológico atender positivamente à diferença cultural, ficando esta dimensão dependente do critério das escolas, que a poderiam contemplar ou não no seu Projecto Educativo.

Ainda do ponto de vista da educação escolar, o D.L. 6/ME/2001 vem consagrar o

\footnotetext{
${ }^{44}$ Para uma análise crítica desta medida de política educativa e da sua aplicação, ver Rui Canário, Natália Alves e Clara Rolo (2001, p. 139), onde os/as autores/as referem que "o que está, no essencial, subjacente à política TEIP é, como no caso da criação dos 'currículos alternativos', uma lógica 'paliativa' que pretende minimizar, ao nível do sistema escolar, os efeitos decorrentes da invasão da escola pelos problemas sociais da 'pobreza' e da 'exclusão'.
} 
Português como língua segunda, referindo, no seu art. $^{\circ} 8^{\circ}$ que "as escolas devem proporcionar actividades curriculares específicas para a aprendizagem da língua portuguesa como segunda língua aos alunos cuja língua materna não seja o Português." Já em 1997, o D.L. 219/97, no seu $\mathrm{art}^{\circ} 16$, referia que os candidatos que ingressem no sistema educativo nacional através do processo de equivalências de habilitações devem beneficiar de apoio pedagógico, sendo que "o apoio pedagógico deve centrar-se na eliminação das dificuldades sentidas pelo estudante, designadamente no domínio da língua portuguesa."

Estas alterações legislativas devem o seu aparecimento à constatação da existência de uma pluralidade de alunos na escola pública portuguesa cuja língua materna não é o português e que evidenciam dificuldades acrescidas no domínio da língua portuguesa. Têm como objectivo aumentar as possibilidades de sucesso escolar e educativo destes alunos, não pelo respeito e atenção à diferença, mas perspectivando o domínio da Língua Portuguesa como forma de acesso à, e assimilação da, cultura dominante.

Não está no entanto consagrado em lei o ensino da língua materna dos alunos imigrantes ou descendentes de imigrantes e minorias étnicas por parte da escola pública, o que significa que o bilinguismo, como reconhecimento das diferenças culturais ou apenas como medida pedagógica de aproximação gradual a uma igualitarização de sucesso educativo, não tem feito parte das preocupações dos governantes portugueses, que remetem este ensino para o domínio familiar. Mas frequentemente acontece também que são as próprias famílias que, como estratégia de sobrevivência e/ou de tentativa de sucesso na sociedade de "acoIhimento", consideram que a cultura e língua de origem deverão fazer parte da educação familiar, devendo a escola ocupar-se em transmitir com sucesso a cultura oficial dominante como forma de ver aumentadas as oportunidades de vida dos seus descendentes. Isto vem demonstrar a necessidade de se estar atento à diversidade de situações emergentes do fenómeno migratório e das diferentes expectativas e formas de integração social e escolar perspectivada por cada minoria e pelos seus diferentes segmentos internos.

No que concerne à Religião, o D.L. n 329/ 98 de 2 de Novembro, relativo ao "Ensino da Religião e Moral não católicas nas escolas", vem consagrar a diversidade religiosa na escola pública, terminando com a exclusividade da religião católica. A partir do ano lectivo de 1999/ 2000, a disciplina facultativa de Educação Moral e Religiosa, existente do $1^{\circ}$ ao $12^{\circ}$ ano, pode ser ministrada por qualquer confissão religiosa estabelecida no país. E apesar do laicismo das instituições educativas públicas portuguesas, não é proibido o uso de símbolos religiosos e/ou o uso de trajes específicos de determinados migrantes e minorias étnicas, não sendo também visível até ao momento qualquer inquietação social neste domínio.

Do ponto de vista das políiticas sociais públicas, em 1996 foi criado o Estatuto do Alto Comissário para as Minorias Étnicas ${ }^{45}$, alterado em 2001 para ACIME - Alto Comissariado para a Imigração e Minorias Étnicas ${ }^{46}$, "com carácter de estrutura interdepartamental de apoio e consulta do governo em matéria de imigração e minorias étnicas", tendo, sob a

\footnotetext{
${ }^{45}$ D.L. 3-A/96, de 16 de Janeiro, sob dependência directa do Primeiro Ministro. Pela importância de que actualmente se reveste este organismo, consideramos importante abordarmos a sua criação, objectivos e funções.

${ }^{46}$ D.L. n ${ }^{\circ}$ 251/2002, de 22 de Novembro, na dependência da Presidência do Conselho de Ministros.
} 
sua alçada, a Comissão para a lgualdade e contra a Discriminação Racial e o Grupo de Trabalho para a lgualdade e Inserção dos $\mathrm{Ci}$ ganos. São atribuições deste Alto Comissariado (art. $2^{\circ}$.), entre outras, "contribuir para a melhoria das condições de vida dos imigrantes em Portugal, de modo que seja proporcionada a sua integração na sociedade no respeito pela sua identidade social e cultural; contribuir para que todos os cidadãos legalmen$\mathrm{te}^{47}$ residentes em Portugal gozem de dignidade e oportunidades idênticas; promover o estudo da temática da inserção das minorias étnicas; colaborar na definição e cooperar na dinamização de políticas activas de integração social e de combate à exclusão".

Desde Janeiro do corrente ano, o Secretariado Entreculturas passou a integrar o ACIME, passando este, a partir daquela data, a englobar também preocupações com a educação escolar dos imigrantes e minorias étnicas. Este organismo oferece apoio legal aos imigrantes e minorias étnicas, tendo criado em vários pontos do país Centros Locais de Apoio ao Imigrante e Centros Nacionais (em Lisboa e no Porto).

Este organismo, através do Observatório da Imigração, tem tido um papel importante no que concerne à produção de estudos sobre imigrantes e minorias étnicas, com impacto ao nível da melhoria da imagem social dos mesmos.

Pode considerar-se que as políticas que desenvolvem procuram promover a igualdade de direitos (civis, sociais e políticos) e alguma discriminação positiva no que concerne ao respeito pelas especificidades culturais de minorias, quer endógenas, quer exógenas. Essas ten- tativas nem sempre são bem conseguidas dado, por exemplo, a Comissão para a lgualdade e contra a Discriminação Racial ter estado inactiva durante bastante tempo (tendo presentemente reiniciado as suas funções) e o Grupo de Trabalho para a lgualdade e Inserção dos Ciganos apresentar, até ao momento, uma importância marginal dado as suas sugestões nem sempre encontrarem eco do ponto de vista político. Isto tem significado uma ausência de repercussões práticas significativas ao nível da melhoria das condições de vida da etnia cigana ou no respeito pela sua cultura.

Este Alto Comissariado, pela elevada concentração de funções que actualmente apresenta, está a constituir-se num dos organismos com maior importância e protagonismo em Portugal no que concerne às políticas de imigração, aos migrantes e minorias étnicas. Esta concentração de valências num mesmo organismo, ao mesmo tempo que aumenta o poder e visibilidade do mesmo, pode no entanto significar a diminuição do grau de importância e a diluição de especificidades inerentes a diferentes problemáticas e campos de análise.

Podemos considerar que, do ponto de vista das políticas sociais públicas, esta medida se constitui numa medida híbrida, que procura simultaneamente criar igualdade de oportunidades, mas também leva a cabo algumas acções de discriminação positiva no que concerne à atenção à diversidade cultural, no sentido de diminuir as injustiças originadas pelas diferenças de ordem cultural.

Em 1996 foi instituído o Rendimento Mínimo Garantido ${ }^{48}$, com o objectivo fun-

\footnotetext{
${ }^{47}$ (Grifo nosso). Isto significa que os imigrantes ilegais têm um "estatuto" de "não-cidadãos", sem direitos, dado não existirem perante a lei.

${ }^{48}$ Lei 19-A/96.
}

Ensaio: aval. pol. públ. Educ., Rio de Janeiro, v.13, n.47, p. 181-216, abr.jun. 2005 
damental de contribuir para o combate à pobreza e à exclusão social incluindo, para além da atribuição de um subsídio pecuniário, programas de inserção profissional. O Rendimento Mínimo Garantido é atribuído ao conjunto do agregado familiar podendo, os diferentes elementos do mesmo, beneficiar de programas diferenciados de inserção social e profissional.

Os agregados familiares, para beneficiarem deste subsídio, têm por obrigação enviar para a escola as crianças e jovens em idade de frequentar a escolaridade obrigatória (até fazerem 16 anos) e, os adultos, quando analfabetos, deverão frequentar o Ensino Recorrente nocturno. No entanto, os efeitos desta obrigatoriedade não se têm revelado, até ao presente, muito positivos. Em relação à escolarização das crianças e jovens, esta medida teve como consequência, no primeiro ano da sua implementação, as escolas serem "invadidas" por crianças (principalmente ciganas) com idades relativamente avançadas a frequentar o primeiro ano de escolaridade, ou seja, crianças tradicionalmente afastadas da escola e adolescentes que há muito tempo tinham abandonado o sistema de ensino. Daqui resultaram elevadas taxas de insucesso escolar uma vez que as escolas e os professores não tinham sido preparados para esta nova realidade.

No que diz respeito à escolarização dos adultos, a sua alfabetização não tem sido bem sucedida dada não ter sido pensada dentro de uma educação de adultos. De resto, a esta população "vem sendo, ainda hoje, consideravelmente dificultado o acesso a ofertas educativas especificamente orientadas segundo as suas características e experiências anteriores, e de acordo com as suas necessida- des e os seus interesses" (LIMA, 2003). Subjacente a esta forma de não pensar a escolarização dentro de uma educação de adultos, está a "ausência de uma política para a educação de adultos" 49 e, "na sua ausência, ou perante a sua debilidade, permanecerão por resolver os problemas relativos à educação e formação da maioria da população adulta [...] em Portugal, em termos de cidadania democrática, de educação em geral e de formação para o mundo do trabalho". ${ }^{50}$

Os programas de inserção incluídos nesta medida passam também por iniciativas no âmbito da saúde (nomeadamente vacinação e planeamento familiar), bem como pela oferta de acções de formação visando a qualificação profissional.

Sendo uma medida que, do ponto de vista do seu articulado, visa fundamentalmente combater a pobreza e a exclusão social (beneficiando dela não só as classes socais desfavorecidas nacionais, mas também os imigrantes e as minorias étnicas, principalmente os oriundos dos PALOP e os ciganos), procurando promover uma maior justiça social, tem também realizado alguma discriminação positiva, nomeadamente pela promoção e desenvolvimento de acções de formação para grupos étnicos específicos (ciganos e imigrantes dos PALOP).

Podemos assim considerar que, do ponto de vista das políticas sociais públicas, quer esta medida, quer a anterior, se constituem em medidas híbridas, que procuram simultaneamente criar igualdade de oportunidades, mas também levam a cabo algumas acções de discriminação positiva no que con-

${ }^{49}$ LIMA, 2003

50 ld., Ibid.

Ensaio: aval. pol. públ. Educ., Rio de Janeiro, v.13, n.47, p. 181-216, abr./jun. 2005 
cerne à atenção à diversidade cultural, no sentido de diminuir as injustiças originadas pelas diferenças de ordem cultural.

Esta Lei foi revogada em 2003, passando a designar-se por Rendimento Social de Inserção ${ }^{51}$. A esta mudança de designação corresponde uma mudança de conteúdo mais em harmonia com uma coligação governamental de Centro-Direita, uma vez que a anterior foi criada por um Governo Socialista, com preocupações sociais relativamente acentuadas, nomeadamente na atribuição de direitos sociais e culturais. $\mathrm{Na}$ presente designação está implícito que a atribuição deste subsídio pode cessar a qualquer momento, deixando desprotegidos agregados familiares extremamente desfavorecidos (por essa razão é que se designa de "inserção": quando esta inserção não se realizar por razões definidas centralmente como atribuíveis aos beneficiários do rendimento, o subsídio é retirado). Para além deste aspecto, as alterações introduzidas ao documento visaram restringir as possibilidades de atribuição deste subsídio. Como podemos ler na introdução do documento, "as principais mudanças introduzidas relativamente ao anterior regime vão no sentido de acentuar o carácter transitório e subsidiário da atribuição da prestação [...]".

Em 1999 foi criada a Lei de Defesa contra a Discriminação Racial ${ }^{52}$, visando combater a discriminação no emprego ou na oferta de emprego, a discriminação no acesso à compra ou arren- damento de imóveis, a discriminação no acesso a locais públicos ou abertos ao público, a discriminação no acesso ao exercício de uma actividade económica ou a discriminação na construção de turmas escolares (por exemplo, proibindo a construção de turmas só com alunos ciganos, africanos ou descendentes de africanos).

Esta lei, embora não revele uma preocupação com o conhecimento e respeito culturais, constitui um avanço importante em termos legislativos no que concerne à igualdade de direitos. No entanto, não tem tido implicações significativas ao nível das práticas quotidianas, dado grande parte dos imigrantes e minorias étnicas desconhecerem a sua existência e, quando conhecem, não saberem a quem recorrer para fazer valer os seus direitos ou recearem serem vítimas de represálias por parte dos organismos ou pessoas responsáveis pela discriminação de que são alvo.

Apesar da importância das opções tomadas pelos governos em matéria da concepção das políticas sociais públicas, os efeitos dessas políticas serão nulos ou muito reduzidos se simultaneamente não se desenvolverem acções de divulgação e sensibilização junto das populações locais visando a incorporação efectiva das mesmas no quotidiano dos cidadãos. $O$ desfasamento entre estes dois níveis tem como consequência a existência de leis relativamente avançadas em vários domínios e práticas sociais marcadas pela desconfiança e o conservadorismo.

\footnotetext{
${ }^{51}$ Lei 13/2003, de 21 de Maio, com Declaração de Rectificação n 7/2003, de 29 de Maio.

52 Lei n ${ }^{\circ} 134 / 99$, de 28 de Agosto.
} 


\section{Algumas reflexões finais}

- Do ponto de vista da socialização e educação familiares, faltam estudos em Portugal que nos permitam conhecer e compreender os significados atribuídos pelos diferentes grupos socioculturais à instituição escolar e aos saberes académicos, articulando esses diferentes significados com os estilos de vida e as estratégias e expectativas em relação à construção de oportunidades de vida ${ }^{53}$.

- Do ponto de vista da educação escolar, não se pode considerar que em Portugal tenha emergido um modelo de educação intercultural (a existir um modelo, este seria enformado e informado por um "pluralismo cultural benigno") ${ }^{54}$. Não existe um currículo de raiz intercultural, mas condescendências pontuais visíveis na construção de alguns manuais e outros materiais de apoio ao trabalho em sala de aula ao nível dos $1^{\circ}$ e $2^{\circ}$ Ciclos do Ensino Básico. Consideramos que a construção de uma educação intercultural não é compatível com condescendências pontuais ao nível do currículo-padrão: a partir do momento em que as diferentes formações sociais dos diferentes Estados-nação considerem a existência de uma cultura oficial escolar e perspectivem a incorporação da diferença étnicocultural nas instituições educativas numa relação de subordinação, inserindo o diferente no hegemónico já existente, a educação intercultural será sempre uma falácia. Ou seja, a partir do momento em que se considere a existência de uma cultura oficial escolar, o máximo de igualdade que a centralidade desta permitirá não será mais do que a emergência de centralidades culturais periféricas ou de marginalidades culturais pontualmente consideradas no currículo-padrão.

A construção da educação intercultural será possível quando todas as culturas forem consideradas oficialmente escolares.

\footnotetext{
${ }^{53}$ De salientar o trabalho já referido, levado a cabo por Teresa Seabra (1999).

${ }^{54}$ Consideramos no entanto que a complexidade das diferentes formações sociais e educativas não se compadecem com soluções ou propostas únicas e acabadas, não existindo "a" solução, "o" modelo de actuação," o" modelo de educação intercultural, mas uma pluralidade de formas de actuação, eventualmente constitutivas de vários modelos, conducentes à construção de uma diversidade de processos de integração sociocultural e de educação intercultural e a aproximações diferenciadas a uma educação intercultural.
} 


\section{Referências}

AFONSO, A. J Educação básica, democracia e cidadania: dilemas e perspectivas. Porto: Edições Afrontamento, 1999.

- Insucesso, socialização escolar e comportamentos divergentes: uma abordagem introdutória. Braga: Universidade do Minho, 1987. (Cadernos de Análise Social da Educação).

ARAÚJO, H. C. Algumas teorias explicativas. Braga: Universidade do Minho, 1987. p. 77-80. (Cadernos de Análise Social da Educação).

- Género, diferença e cidadania na escola: caminhos abertos para a mudança social. In: RODRIGUES, D. (Org.). Educação e diferença. Porto: Porto Editora, 2001 a.

Há já lugar para algum mapeamento nos estudos sobre género e educação em Portugal? uma tentativa exploratória. Investigar em Educação, Lisboa, p. 101-145, 2002.

. O masculino e o feminino e a escola democrática. In: TRIGUEROS, T. (Org.) Hacia una pedagogia de la igualdad. Salamanca: Amarú Ediciones, 1998.

BAGANHA, M. I. A cada sul o seu norte: dinâmicas migratórias em Portugal. In:

SANTOS, B. S. (Org.). Globalização: fatalidade ou utopia? Porto: Edições Afrontamento, 2001.

BAGANHA, M. I.; FERRÃO, J.; MALHEIROS, J. Os movimentos migratórios externos e a sua incidência no mercado de trabalho em Portugal. Lisboa: Instituto de Emprego e Formação Profissional, 1998.

BAGANHA, M. I.; GÓIS, P. Migrações internacionais de e para Portugal: o que sabemos e para onde vamos? Revista Crítica de Ciências Sociais, Lisboa, n. 52/53, p.229-280, $1998 / 1999$.

BARRENO, I. O falso neutro. Lisboa: Edições Rolim, 1985.

BENAVENTE, A. O insucesso escolar no contexto português: abordagens, concepções e políticas. Análise Social, Lisboa, v. 25, n. 108/109, p. 715-733, 1990 a.

BENAVENTE, A.; CORREIA, M. A. P. Obstáculos ao sucesso na escola primária. Lisboa: Instituto de Estudos para o Desenvolvimento, 1981. (Caderno n. 3).

BENAVENTE, A. et al. Renunciar à escola: o abandono escolar no ensino básico.

Lisboa: Fim de Século, 1994. 
BOURDIEU, P.; CHAMPAGNE, P. Os excluídos do interior. In: BOURDIEU, P. (Org.). A miséria do mundo. Petrópolis: Editora Vozes, 1997.

BOURDIEU, P.; PASSERON, J. C. A reprodução: elementos para uma teoria do sistema de ensino. Lisboa: Ed. Vega, 1972.

CANÁRIO, R.; ALVES, N.; ROLO, C. Escola e exclusão social. Lisboa: Educa, 2001.

CARRASCO, S. et al. Reflexiones desde la investigación en el nuevo contexto multicultural de Cataluña. Nómadas, Santafé de Bogotá, n. 14, p. 50-66, 2001.

CASA-NOVA, M. J. Ciganos, escola e mercado de trabalho. Revista Galego-Portuguesa de Psicoloxía e Educación, Braga, ano 7, v. 10, n. 8, p. 252-268, 2003a.

. Construindo a educação inter/multicultural crítica. In: COLÓQUIO DA AFIRSE/

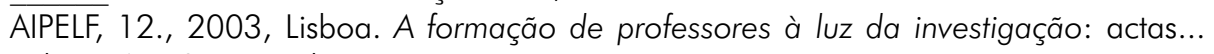
Lisboa: AFIRSE, 2003b. v. 2, p. 1150-1158.

- Etnicidade e classes sociais: em torno do valor heurístico da conceptualização da etnia como categoria social. Educação, Sociedade \& Culturas, Porto, n. 16, p. 6382,2001 a.

. Etnicidade e educação familiar: o caso dos ciganos. In: CONGRESSO DA ASSOCIAÇÃO PORTUGUESA DE SOCIOLOGIA, 5., 2004, Braga. Actas... Braga: Universidade do Minho, 2004. No prelo.

. Etnicidade, género e escolaridade: estudo em torno das socializações familiares de género numa comunidade cigana da periferia da cidade do Porto. Dissertação (Mestrado)-Faculdade de Psicologia e de Ciências da Educação, Universidade do Porto, Porto, 1999.

. Etnicidade, género e escolaridade. Lisboa: IIE, 2002.

Gypsy culture, children, schooling and life opportunities. In: CARRASCO, S. (Ed.). Between diversity and inequality: children's experiences of life and school in multicultural Europe. Barcelona: CIIMU, 2004b. (Nueva Colección Urban Chilhood research monographs; n. 1). Disponível em:<http://www.ciimu.org. $>$. Acesso em: 13 jun. 2005. No prelo.

- Sociedades e escolas multiculturais: esboço de um quadro teórico para análise das práticas. Revista de Administração Educacional, Recife, BR, v. 1, n. 7, p. 69-90, $2001 b$. 
CORTESÃO, L.; PACHECO, N. Interculturalismo e realidade portuguesa. Inovação: revista do Instituto de Inovação Educacional, [Lisboa], v. 4, n. 2/3, p. 33-44, 1991.

CORTESÃO, L.; STOER, S. R. Cartografando a transnacionalização do campo educativo: o caso português. In: SANTOS, B. S. (Org.). Globalização: fatalidade ou utopia? Porto. Edições Afrontamento, 2001.

A interculturalidade e a educação escolar: dispositivos pedagógicos e a construção da ponte entre culturas. Inovação: revista do Instituto de Inovação Educacional, [Lisboa], v. 9, n. 1/2, p. 35-51, 1996.

- Investigação-acção e a produção de conhecimento no âmbito de uma formação de professores para a educação inter/multicultural. Educação, Sociedade \& Culturas, Porto, n. 7, p. 7-28, 1997.

- Projectos, percursos, sinergias no campo da educação inter/multicultura: relatório final. Porto: Faculdade de Psicologia e de Ciências da Educação, 1995.

CORTESÃO, L. et al. E agora tu dizias que ...: jogos e brincadeiras como dispositivos pedagógicos. Porto: Edições Afrontamento, 1995.

- Mergulhando no arco-íris sociocultural: contributo para o conhecimento dos trabalhos sobre educação e diversidade em Portugal. Investigar em Educação, Lisboa, v. 1, n. 1, p. 19-99, 2002.

DIETZ, G. Multiculturalismo, interculturalidad y educación: una aproximación antropológica. Granada: Editorial Universidad de Granada, 2003.

ENGUITA, M. Etnicidade e escola: o caso dos ciganos. Educação, Sociedade \& Culturas, Porto, n. 6, p. 5-22, 1996.

ESTÊVÃO, C. A. Justiça complexa e educação: uma reflexão sobre a dialectologia da justiça. Revista Crítica de Ciências Sociais, Coimbra, n. 64, p.107-134, 2002.

. Justiça e educação. São Paulo: Cortez, 2001.

FERREIRA, A. M. M. Desigualdades de género no actual sistema educativo português. Coimbra: Quarteto Editora, 2002.

FONSECA, L. Culturas juvenis, percursos femininos: experiências e subjectividades na educação de raparigas. Lisboa: Celta Editora, 2001.

FONTAINE, A. M. A discriminação sexual dos papéis sociais nos manuais portugueses 
de aprendizagem de leitura. Coimbra: Faculdade de Letras, 1977.

FORMOSINHO, J. A influência dos factores sociais. Braga: Universidade do Minho, 1987. (Cadernos de Análise Social da Educação).

GARCIA, J. L. Portugal migrante. Oeiras: Celta Editora, 2000.

GOMES, C. A interacção selectiva na escola de massas. Sociologia, Problemas e Práticas, Lisboa, n. 3, p. 35-49, 1987.

GRÁCIO, S.; MIRANDA, S. Insucesso escolar e origem social: resultados de um inquérito: piloto. Análise Social, Oeiras, n. 51, p. 721-726, 1977.

HABERMAS, J. Lutas pelo reconhecimento no Estado democrático constitucional. In: TAYLOR, C. et al. (Org.). Multiculturalismo: examinando a política de reconhecimento. Lisboa: Instituto Piaget, 1998.

HENRIQUES, F. Igualdades e diferenças. Porto: Porto Editora, 1994.

ITURRA, R. A construção social do insucesso escolar. Lisboa: Escher, 1990a.

Fugirás à escola para trabalhar a terra. Lisboa: Escher, 1990b.

LEITE, C. O currículo e o multiculturalismo no sistema educativo português. Lisboa: Fundação Calouste Gulbenkian, 2002a.

. O multiculturalismo na educação escolar: que estratégias numa mudança curricular? Inovação: revista do Instituto de Inovação Educacional, [Lisboa], v. 9, n. 1/2, p. 63-81, 1996.

. Para uma escola curricularmente inteligente. Porto: Edições ASA, 2002b.

LIMA, L. Igualdade de oportunidades de sucesso. Braga: Universidade do Minho, 1987. p. 65-69. (Cadernos de Análise Social da Educação).

. A escola como organização e a participação na organização escolar. Braga:

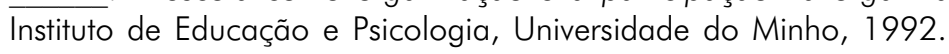

Formação e aprendizagem ao longo da vida: entre a mão direita e a mão esquerda de Miro. In: ALMEIDA, J. F. (Org.). Cruzamento de saberes: aprendizagens sustentáveis. Lisboa: Fundação Calouste Gulbenkian, p. 129-148, 2003. 
McCARTHY, C. Racismo y curriculum, Madrid: Ed. Morata, 1994.

MACHADO, F. L. Contrastes e continuidades. Oeiras: Celta Editora, 2002.

MATOS, I. A. O ensino de português língua segunda e português língua estrangeira: situação actual. In: COLÓQUIO ANUAL INTERNACIONAL LUSOFONIA SLP NORTE, 2., 2003, Bragança. Lusofonia: diversidades culturais: actas ... Bragança, PT: SLP Norte, 2003. Disponível em: <http://slp2003.com.sapo.pt>. Acesso em: 14 jun. 2005.

PACHECO, N. Da luta anti-racista à educação intercultural. Inovação: revista do Instituto de Inovação Educacional, [Lisboa], v. 9, n. 1/2, p. 53-62, 1996.

SEABRA, T. Educação nas famílias: etnicidade e classes sociais. Lisboa: IIE, 1999.

SEABRA, T.; MATEUS, S. Os descendentes de imigrantes na escola pública portuguesa: contingente, localização e resultados. Revista Galego-Portuguesa de Psicoloxía e Educación, Coruña, ES, ano 7, v. 10, n. 8, p. 820-833, 2003.

SILVA, M. B. N. et al. Emigração/imigração em Portugal. In: COLÓQUIO INTERNACIONAL SOBRE EMIGRAÇÃO E IMIGRAÇÃO PORTUGUESA: séculos XIX e XX, 1993, Algés. Actas ... Lisboa: Editorial Fragmentos, 1993.

SILVA, P. Escola-família, uma relação armadilhada? Ensaios de Educação Participada, Santarém, n. 11, p. 23-30, 1993.

. Escola-família, uma relação armadilhada: interculturalidade e relações de poder. Porto: Edições Afrontamento, 2003.

. Pais-professores: uma relação em que uns são mais iguais do que outros? Educação, Sociedade \& Culturas, Porto, n. 6, p. 179-190, 1996.

SILVA, T. T. Distribuição do conhecimento escolar e reprodução social. Educação e Realidade, Porto Alegre, v. 13, n. 1, p. 3-16, 1988.

SOUTA, L. Multiculturalidade \& educação. Porto: Profedições, 1997.

STOER, R. S. Combatendo a educação multicultural benigna. In: COLÓQUIO UM OLHAR SOBRE O OUTRO, 1997, Lisboa. Actas ... Lisboa: Departamento de Ensino Básico, 1999.

- Construindo a escola democrática através do campo da recontextualização pedagógica. Educação, Sociedade \& Culturas, Porto, n. 1, p. 7-27, 1994. 
STOER, R. S. Desocultando o voo das andorinhas: educação inter-multicultural crítica como movimento social. In: STOER, S.; CORTESÃO, L.; CORREIA, J. A. (Org.). Transnacionalização da educação: da crise da educação à educação da crise. Porto: Edições Afrontamento, 2001. p. 245-275.

A reforma educativa e a formação de professores em Portugal: perspectivas inter/multiculturais. In: NÓVOA, A.; POPKEWITZ, T. (Org.). Reformas educativas e formação de professores. Lisboa: Educa, 1992.

STOER, S. R.; CORTESÃO, L. Levantando a pedra: da pedagogia inter-multicultural às políticas educativas numa época de transnacionalização. Porto: Edições Afrontamento, 1999.

VIEIRA, R. Histórias de vida e identidades: professores e interculturalidade. Porto: Edições Afrontamento, 1999a.

- Mentalidades, escola e pedagogia intercultural. In: Educação, Sociedade \& Culturas, Porto, n. 4, p. 127-145, 1995. $\overline{1999 b .}$

. Ser igual, ser diferente: encruzilhadas da identidade. Porto: Profedições;

Recebido: 13/05/2005

Aceito para publicação em: 13/06/2005 


\section{ANEXOS}

\section{Quadro 1}

Evolução da imigração em Portugal (dados do SEF - Serviço de Estrangeiros e Fronteiras)

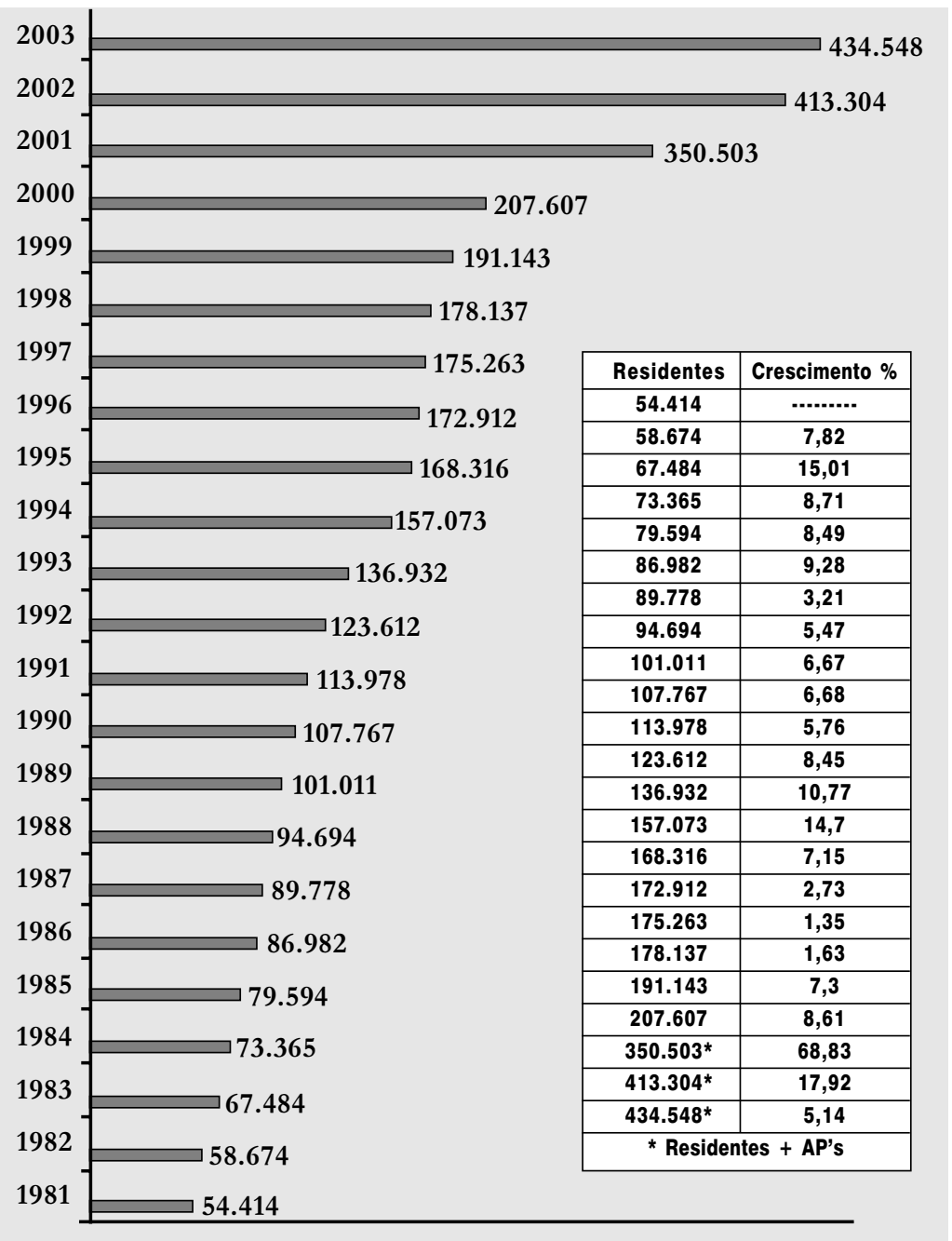




\section{Quadro 2}

Imigrantes Residentes e com Autorização de Permanência em Portugal segundo os países de origem mais representados (Dados provisórios de 2004)

\begin{tabular}{|ll|}
\hline Brasil & 77.000 \\
\hline Ucrânia & 67.745 \\
\hline Cabo Verde & 63.887 \\
\hline Angola & 35.122 \\
\hline Guiné & 23.068 \\
\hline Reino Unido & 16.784 \\
\hline Espanha & 15.329 \\
\hline Alemanha & 12.519 \\
\hline Moldávia & 12.399 \\
\hline Roménia & 11.146 \\
\hline França & 8.851 \\
\hline E.U.A. & 8.026 \\
\hline S. Tomé e Príncipe & 7.535 \\
\hline Rússia & 7.218 \\
\hline Países Baixos & 5.075 \\
\hline Moçambique & 4.025 \\
\hline China & 4.835 \\
\hline Itália & 4.176 \\
\hline
\end{tabular}

(Quadro elaborado a partir de dados do SEF - Serviço de Estrangeiros e Fronteiras) 


\section{Quadro 3}

\begin{tabular}{|c|c|c|c|c|c|c|c|c|c|c|c|c|c|c|c|}
\hline \multirow{3}{*}{\begin{tabular}{l}
$\infty$ \\
$\stackrel{\infty}{\pi}$ \\
\multirow{\sigma}{\sigma}{} \\
$\sigma$
\end{tabular}} & 。 $E$ & $\infty$ & $R$ & 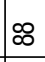 & 뇽 & $\infty$ & চ & $\bar{\infty}$ & ஜ & б. & ठ & б & $\infty$ & б & 8 \\
\hline & $\begin{array}{l}\text { 읗 } \\
\text { o } \\
\text { \& }\end{array}$ & 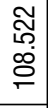 & 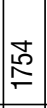 & 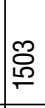 & 过 & ले & 空 & ลิ & 으 & $\stackrel{\sim}{\sim}$ & $\ddot{m}$ & 芯 & 灾 & 은 & $\approx$ \\
\hline & $\begin{array}{ll}\text { 8 } & \\
\text { ㅇ } & \text { 은 } \\
\circ & 0 \\
\end{array}$ & 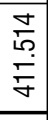 & $\frac{R}{6}$ & 焉 & 尽 & 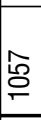 & 응 & 店 & E & 8 & 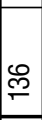 & 吕 & 令 & న్రి & 뉴 \\
\hline \multirow{3}{*}{$\begin{array}{l}\hat{\sigma} \\
\stackrel{5}{\circ} \\
\sigma\end{array}$} & $\circ \equiv$ & $\infty$ & 咅 & ळ & 字 & 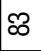 & வ & ळ & ஜ & $\mathscr{8}$ & N & б & $\infty$ & 8 & 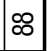 \\
\hline & $\begin{array}{l}\text { 릍 } \\
\text { i }\end{array}$ & 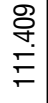 & $\underset{\mathbb{N}}{\underline{N}}$ & 吕 & $\overline{\check{\infty}}$ & 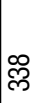 & శ్లి & $\stackrel{\Delta}{\sim}$ & 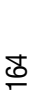 & $\approx$ & $\approx$ & 太 & $\tilde{N}$ & స్ & $\underset{\mathbb{N}}{\mathbb{N}}$ \\
\hline & 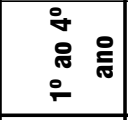 & 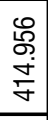 & $\overline{8}$ & $\begin{array}{l}\hat{N} \\
\tilde{\tilde{N}} \\
\end{array}$ & 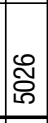 & 움 & \%ิ으. & 范 & 8 & ๙ & $\stackrel{\circ}{\rightleftharpoons}$ & న్ & $\stackrel{\widetilde{m}}{\sim}$ & 只 & స̃ \\
\hline \multirow{3}{*}{ 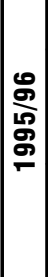 } & $\therefore E$ & 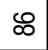 & م & 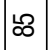 & ח & $R$ & б & 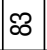 & $\delta$ & 으 & 8 & ठ & ஜ & б & $\infty$ \\
\hline & $\begin{array}{l}\stackrel{0}{\bar{E}} \\
\text { 巳 }\end{array}$ & 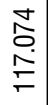 & ஜ్ֶరి & 尽 & 棁 & స్లి & 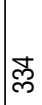 & 总 & 尺ి & $\approx$ & $\mathscr{F}$ & ஜ्ల & त्र & 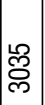 & $\stackrel{R}{N}$ \\
\hline & 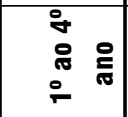 & 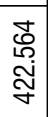 & $\begin{array}{l}\text { g) } \\
\text { ले } \\
6\end{array}$ & $\begin{array}{l}8 \\
0 \\
0 \\
10\end{array}$ & 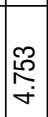 & $\stackrel{\text { }}{\stackrel{\overbrace{}}{ָ}}$ & $\underset{\mathscr{O}}{\stackrel{\circ}{-}}$ & 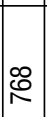 & 유 & 8 & 8 & ৪্ণ & 胥 & 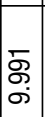 & 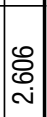 \\
\hline \multirow{3}{*}{ 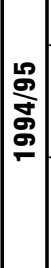 } & $\therefore$ & $\varnothing$ & $R$ & 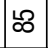 & 5 & $\infty$ & б & $\infty$ & 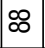 & $\infty$ & N & ภ & $\infty$ & ৪) & $\infty$ \\
\hline & $\begin{array}{l}\stackrel{0}{\pi} \\
\text { i }\end{array}$ & 总 & $\stackrel{\circ}{\grave{N}}$ & 导 & $\varnothing$ & ल्ल & 胥 & 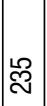 & 욤 & $\infty$ & R & ฌ్లి & 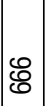 & $\frac{m}{\infty}$ & 호 \\
\hline & 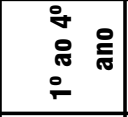 & 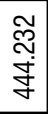 & $\frac{m}{\square}$ & \begin{tabular}{l}
\multirow{N}{*}{} \\
$\hat{\sigma}$ \\
$\dot{\forall}$ \\
\end{tabular} & \begin{tabular}{|l}
$\pi$ \\
$\hat{\sigma}$ \\
$\forall$ \\
\end{tabular} & $\underset{ }{\stackrel{\Gamma}{N}}$ & $\underset{ }{\stackrel{g}{+}}$ & $\approx$ & 冓 & $\approx$ & 을 & 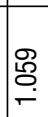 & $\frac{\mathscr{O}}{\underset{\sim}{\sim}}$ & 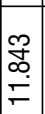 & $\begin{array}{l}\infty \\
\stackrel{0}{0} \\
\ddot{m}\end{array}$ \\
\hline \multirow{3}{*}{ 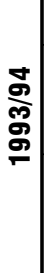 } & $\therefore \equiv$ & $\infty$ & $\infty$ & $\infty$ & 요 & 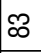 & ภ & 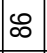 & ช & 음 & 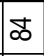 & 18 & ৪ & $\bar{\sigma}$ & ஜ \\
\hline & $\begin{array}{l}\stackrel{0}{\bar{E}} \\
\text { ¿ }\end{array}$ & $\begin{array}{l}\text { Oे } \\
\text { + } \\
\text { ले }\end{array}$ & & $\underset{\Xi}{\Xi}$ & $\frac{7}{6}$ & Б্ & ‡ & ని & 응 & $\infty$ & ผ & 菺 & 央 & 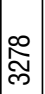 & 守 \\
\hline & $\begin{array}{ll}0 & 0 \\
0 & 0 \\
\circ & \bar{E}\end{array}$ & $\begin{array}{l}\frac{1}{2} \\
\stackrel{m}{\vdots} \\
\stackrel{f}{f}\end{array}$ & $\begin{array}{l}0 \\
\mathbb{0} \\
0 \\
0 \\
\end{array}$ & $\mid \begin{array}{c}\mathscr{\infty} \\
\mathscr{\sim} \\
\stackrel{\sim}{*}\end{array}$ & 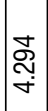 & $\stackrel{\infty}{\stackrel{\infty}{\leftrightarrows}}$ & $\underset{\text { S }}{\mathcal{E}}$ & 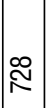 & $\stackrel{\infty}{\infty}$ & o & $\stackrel{\Xi}{I}$ & 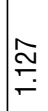 & 灾 & $\begin{array}{l}\frac{0}{0} \\
\\
\end{array}$ & $\begin{array}{c}\infty \\
\stackrel{\infty}{\infty} \\
\dot{\forall}\end{array}$ \\
\hline 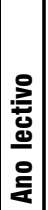 & 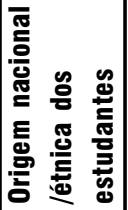 & 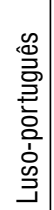 & 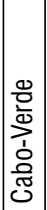 & \begin{tabular}{|l|} 
\\
$\frac{\pi}{8}$ \\
$\frac{2}{2}$ \\
\end{tabular} & 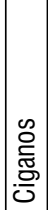 & 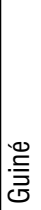 & 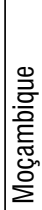 & 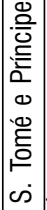 & 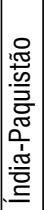 & 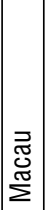 & 高 & $\begin{array}{l}\overline{\bar{c}} \\
\overline{\frac{\pi}{\omega}}\end{array}$ & 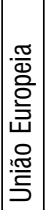 & 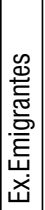 & 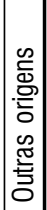 \\
\hline
\end{tabular}




\section{Quadro 4}

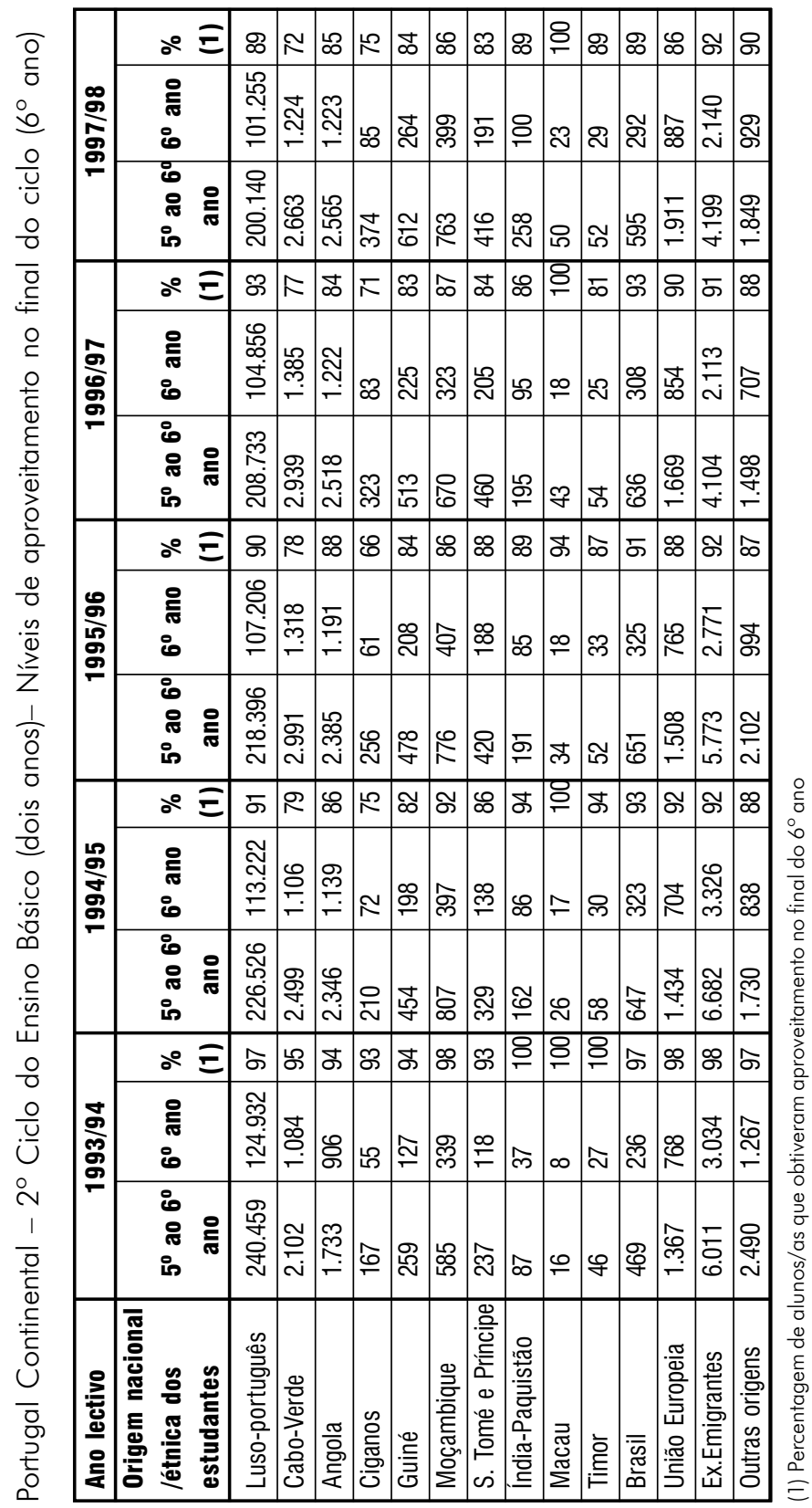




\section{Quadro 5}

\begin{tabular}{|c|c|c|c|c|c|c|c|c|c|c|c|c|c|c|c|}
\hline \multirow{3}{*}{ 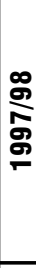 } & $\therefore \equiv$ & 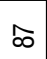 & $R$ & $R$ & ष & T & 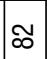 & $\infty$ & ळ & 으 & ஐ & 8 & 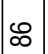 & ஜ & 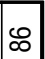 \\
\hline & $\begin{array}{l}\text { 은 } \\
\text { : } \\
\text { : }\end{array}$ & 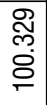 & 잉 & 号 & $=$ & 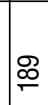 & ஜ্লি & 15 & 8 & $\infty$ & $\stackrel{\sim}{N}$ & 符 & 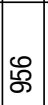 & \begin{tabular}{l}
$\stackrel{2}{+}$ \\
\multirow{\sim}{*}{}
\end{tabular} & జ \\
\hline & 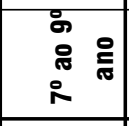 & 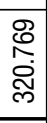 & ్ֶర్ల & 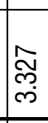 & $\approx$ & ஜ্ర & $\stackrel{8}{\circ}$ & $\bar{్}$ & $\underset{\sim}{\mathbb{N}}$ & 8 & م) & $\begin{array}{l}0 \\
\stackrel{0}{0} \\
-\end{array}$ & $\begin{array}{c}\bar{\aleph} \\
\stackrel{\sim}{\sim}\end{array}$ & $\begin{array}{l}0 \\
\infty \\
\\
\end{array}$ & 柋 \\
\hline \multirow{3}{*}{ 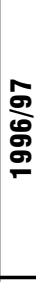 } & $\therefore E$ & 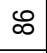 & $\stackrel{\infty}{\infty}$ & 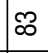 & ஜ & $\stackrel{0}{1}$ & 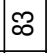 & $\infty$ & $œ$ & ஜ & 8 & 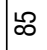 & 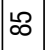 & 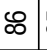 & 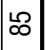 \\
\hline & $\begin{array}{l}\text { 음 } \\
\text { 8े }\end{array}$ & $\begin{array}{l}\text { ஜ্ণ } \\
\text { ঠ் }\end{array}$ & రิ & 8 & 은 & $\bar{m}$ & 芦 & 兽 & $\varnothing$ & $\cong$ & $\approx$ & స్లి & 官 & 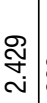 & $\ddot{\circ}$ \\
\hline & 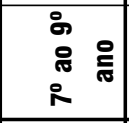 & $\begin{array}{l}\text { ర్లి } \\
\text { స్లై } \\
\end{array}$ & $\begin{array}{l}\text { 导 } \\
\stackrel{\mathrm{N}}{*}\end{array}$ & 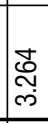 & 5 & 足 & 总 & 芯 & 吕 & 过 & 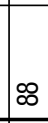 & 总 & 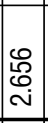 & $\begin{array}{l}\widehat{m} \\
0 \\
\infty\end{array}$ & 文 \\
\hline \multirow{3}{*}{ 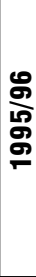 } & 。 $E$ & 8 & $\stackrel{\infty}{\infty}$ & $\infty$ & 10 & R & 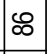 & $\varnothing$ & ภ & $\varnothing$ & க & 8 & 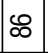 & $\infty$ & 8 \\
\hline & $\begin{array}{l}\text { 읗 } \\
\text { ¿ }\end{array}$ & $\begin{array}{l}\frac{m}{\infty} \\
\vdots \\
\sigma\end{array}$ & 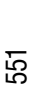 & 尽 & 으 & $\stackrel{2}{\simeq}$ & 号 & $\stackrel{\infty}{\mp}$ & 馆 & $\infty$ & $\ddot{\infty}$ & $\stackrel{\sim}{m}$ & $\mathscr{\infty}$ & 悹 & స్ \\
\hline & 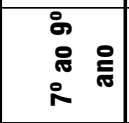 & 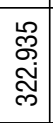 & $\underset{\underset{N}{\sim}}{\text { N }}$ & 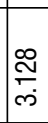 & 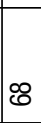 & 字 & 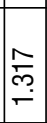 & ஜ & న్స & 用 & 8 & 旡 & 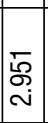 & 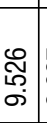 & స్ \\
\hline \multirow{3}{*}{ 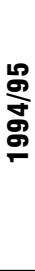 } & $\therefore \bar{E}$ & Б & ळ & $\infty$ & ชั & ஜ & $\infty$ & б & $\infty$ & ठ্ & $\infty$ & ஜ & ৪) & க & $\mathscr{8}$ \\
\hline & $\begin{array}{l}\text { 을 } \\
\text { க) }\end{array}$ & 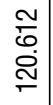 & ర్లి & ஜু & $\simeq$ & $\stackrel{\nabla}{\mp}$ & 预 & ஜ & 8 & $\cong$ & প্ল & $\frac{\circ}{m}$ & 迢 & $\begin{array}{c}\tilde{\sigma} \\
\dot{\sigma} \\
\text { m. }\end{array}$ & 竎 \\
\hline & $\begin{array}{ll}\text { 8) } & \\
\text { ㅇ } & \text { 응 } \\
i & \end{array}$ & 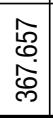 & 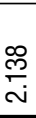 & 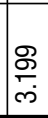 & 8 & $\widetilde{\Psi}$ & 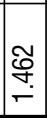 & 㕣 & ळ & 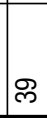 & ช & 음 & 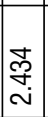 & 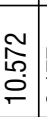 & $\underset{N}{\stackrel{N}{N}}$ \\
\hline \multirow{3}{*}{ 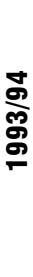 } & $\circ \equiv$ & ஜ & $\infty$ & $œ$ & $\hat{\sigma}$ & $\infty$ & 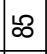 & வ & ஓ & 음 & $\widehat{0}$ & б & $\bar{\sigma}$ & ठ & 8 \\
\hline & $\begin{array}{l}\text { 응 } \\
\text { \& }\end{array}$ & 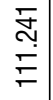 & Бू & ஜ & $\nabla$ & 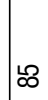 & ర్ల & กิ & 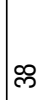 & o & m & $\infty$ & 送 & 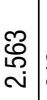 & $\frac{0}{\infty}$ \\
\hline & $\begin{array}{ll}\dot{8} & \\
\text { ㅇ } & \text { 은 } \\
i & \end{array}$ & $\begin{array}{l}\overline{\tilde{n}} \\
\tilde{ర} \\
\text { }\end{array}$ & م & $\frac{0}{i n}$ & $\approx$ & L্ల & 㐫 & 周 & 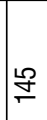 & $\bar{N}$ & $\approx$ & $\frac{\infty}{\widehat{6}}$ & $\mid \begin{array}{c}\tilde{ల} \\
\text { } \\
\text { N. }\end{array}$ & $\begin{array}{l}\mathscr{D} \\
\tilde{\delta} \\
\dot{\sigma}\end{array}$ & 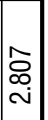 \\
\hline 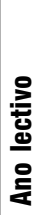 & 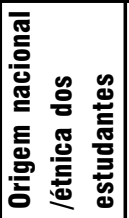 & 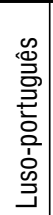 & 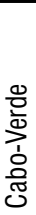 & $\begin{array}{l}\text { 응 } \\
\frac{0}{2}\end{array}$ & 哭 & ه & 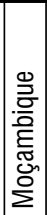 & 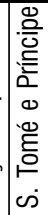 & 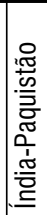 & 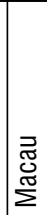 & i & $\begin{array}{l}\overline{\bar{m}} \\
\widetilde{\tilde{D}} \\
\bar{\omega}\end{array}$ & 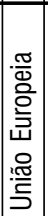 & 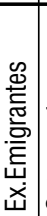 & 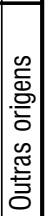 \\
\hline
\end{tabular}




\section{Quadro 6}

\begin{tabular}{|c|c|c|c|c|c|c|c|c|c|c|c|c|c|c|c|}
\hline \multirow{3}{*}{ 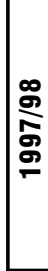 } & $\circ \equiv$ & 8 & $\widetilde{\Xi}$ & م & 음 & గ & 68 & 8 & 18 & $\hat{\theta}$ & 음 & $\bar{\sigma}$ & 8 & $\bar{\sigma}$ & in \\
\hline & \begin{tabular}{|l|} 
O \\
స్ \\
ָิ \\
\end{tabular} & $\begin{array}{l}\mathscr{L} \\
\stackrel{\infty}{\infty} \\
\end{array}$ & 웅 & శ్ర్ర & $\nabla$ & ஜ & $\stackrel{0}{\stackrel{0}{m}}$ & 8 & প্ল & 으 & ما & 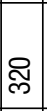 & $\bar{\sigma}$ & 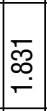 & 饣ึ \\
\hline & 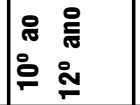 & 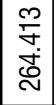 & $\overline{ু ~}$ & & 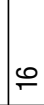 & 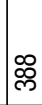 & 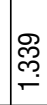 & 尺্ & $\cong$ & ধ & 8 & $\underset{\mathscr{O}}{\mathscr{O}}$ & $\begin{array}{c}\widetilde{O} \\
\stackrel{\mathbb{N}}{\mathrm{N}}\end{array}$ & 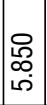 & 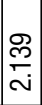 \\
\hline \multirow{3}{*}{ 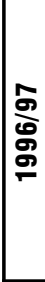 } & $\therefore \equiv$ & 8 & 8 & กิ & 8 & $\infty$ & $\hat{\omega}$ & 芯 & வ & 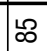 & $\stackrel{\infty}{\circ}$ & 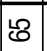 & 8 & $\mathbb{G}$ & 8 \\
\hline & \begin{tabular}{|l} 
O \\
Ẽ \\
సิ
\end{tabular} & $\begin{array}{l}\infty \\
\infty \\
\ddot{\delta} \\
\ddot{\infty}\end{array}$ & ڤ్లి & ָָ & $\sim$ & $\underline{E}$ & శ్రి & $\stackrel{\Xi}{I}$ & $\mathscr{F}$ & $\stackrel{N}{N}$ & $\approx$ & 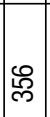 & 实 & 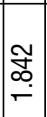 & 递 \\
\hline & 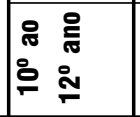 & 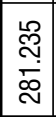 & $\stackrel{\circ}{\circ}$ & i̊ & $\stackrel{2}{2}$ & 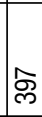 & $\stackrel{\sim}{\sim}$ & $\widetilde{d}$ & 跎 & in & $\widetilde{0}$ & $\ddot{\infty}$ & 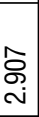 & $\begin{array}{l}\bar{\infty} \\
0 \\
0 \\
0\end{array}$ & 㫋 \\
\hline \multirow{3}{*}{ 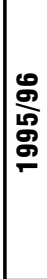 } & $\circ \equiv$ & $\mathbb{N}$ & 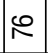 & 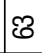 & 요 & 8 & $\hat{\theta}$ & 88 & 8 & 8 & $\mathscr{q}$ & $N$ & R & $\tau$ & $\mathbb{N}$ \\
\hline & 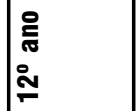 & $\begin{array}{l}\infty \\
\text { ָ̦ } \\
\text { ๙్ర }\end{array}$ & 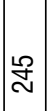 & ִָ & $\sim$ & $\underline{N}$ & হু & $\approx$ & $\infty$ & 으 & $\approx$ & ஜ্লি & \&్రి & $\begin{array}{l}\mathbb{N} \\
\hat{D} \\
\sim\end{array}$ & 部 \\
\hline & 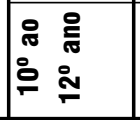 & 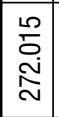 & ৪ & ల్ & $\mp$ & 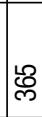 & 苂 & $\mathscr{\widetilde { N }}$ & $\stackrel{m}{\dddot{m}}$ & 8 & $\bar{\infty}$ & $\overline{\mathscr{\delta}}$ & 只 & $\frac{0}{6}$ & $\underset{\sim}{\stackrel{⿰}{\sim}}$ \\
\hline \multirow{3}{*}{ 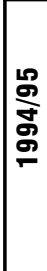 } & $\therefore$ & 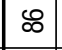 & 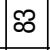 & $\hat{0}$ & 0 & $\widehat{\theta}$ & 8 & ర & 8 & $R$ & 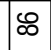 & $\mathbb{N}$ & 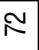 & $\infty$ & N \\
\hline & $\begin{array}{l}\text { 은 } \\
\text { సి } \\
\text { I }\end{array}$ & 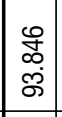 & 志 & চ্চি & 0 & $\approx$ & $\tilde{\Sigma}$ & g্ & $\approx$ & 으 & $\approx$ & స్ & ס & \begin{tabular}{l}
$\mathscr{8}$ \\
$\infty$ \\
\hdashline \\
-
\end{tabular} & $\frac{10}{m}$ \\
\hline & 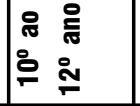 & 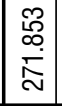 & 胥 & & $\checkmark$ & నิ & : & 8 & $\pi$ & $\stackrel{N}{\sim}$ & $\stackrel{\circ}{\circ}$ & $\frac{\sim}{0}$ & 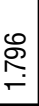 & $\begin{array}{l}\tilde{y} \\
6 \\
\omega \\
\omega\end{array}$ & \begin{tabular}{l}
$\infty$ \\
$\stackrel{\infty}{-}$ \\
\hdashline
\end{tabular} \\
\hline \multirow{3}{*}{ 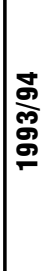 } & $\circ E$ & , & I & , & I & ' & , & , & ' & , & I & I & , & , & , \\
\hline & 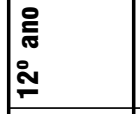 & ' & ' & ' & ' & ' & . & ' & ' & . & ' & ' & ' & I & . \\
\hline & $\begin{array}{ll}\text { 옹 } & \text { 을 } \\
\text { 으 } & \text { సి }\end{array}$ & ' & ' & ' & ' & ' & ' & , & ' & ' & ' & ' & ' & ' & ' \\
\hline 递 & 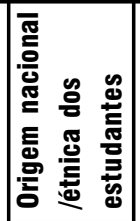 & 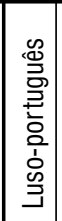 & 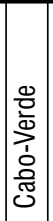 & 范 & 告 & 兽 & 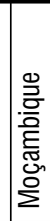 & 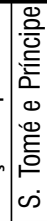 & 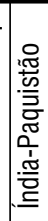 & స్త్ & i & 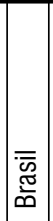 & 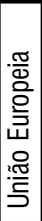 & 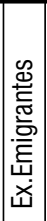 & 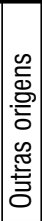 \\
\hline
\end{tabular}

